
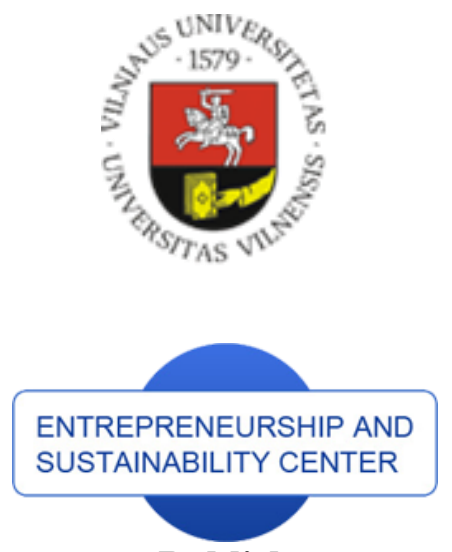

Publisher

http://jssidoi.org/esc/home
ISSN 2345-0282 (online) http://jssidoi.org/jesi/
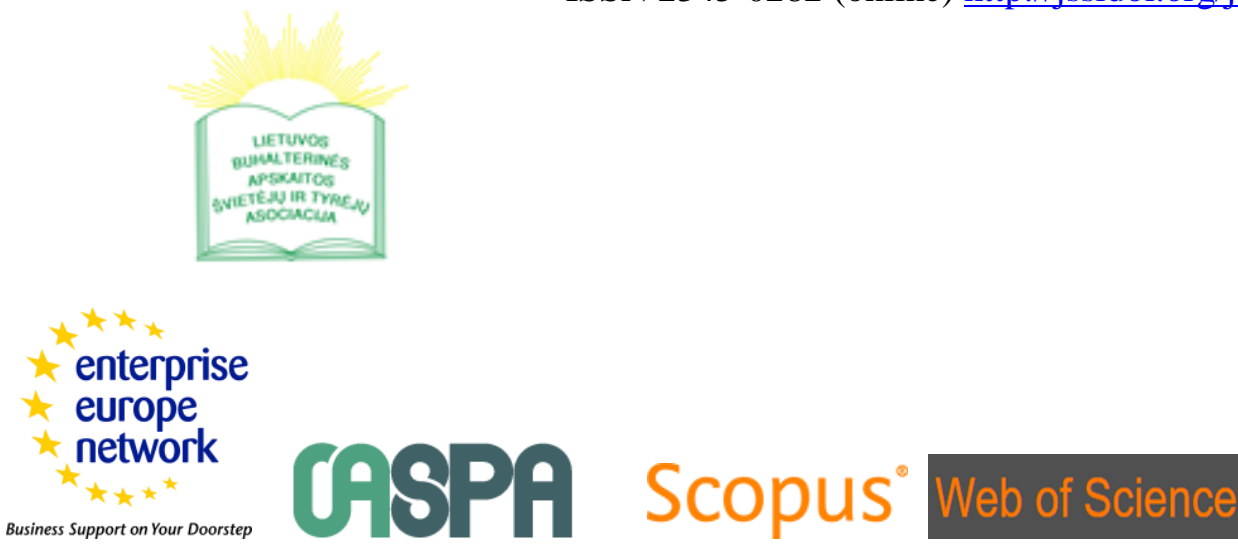

1) Clarivate Analytics

\title{
Publisher
}

\section{EVALUATION OF ACCOUNTING REGULATION EVOLUTION IN SELECTED COUNTRIES}

\author{
Rasa Subačienė $\dot{1}^{1}$ Lehte Alver ${ }^{2}$, Inta Brūna ${ }^{3}$, Mirjana Hladika ${ }^{4}$, Daša Mokošová ${ }^{5}$, \\ Jan Molín 6
}

${ }^{1}$ Vilnius University, Universiteto 3, Vilnius, LT-01513, Republic of Lithuania

${ }^{2}$ Tallinn University of Technology, Ehitajate tee 5, Tallinn 19086, Estonia

${ }^{3}$ University of Latvia, Aspazijas bulv.5, Riga, LV 1050, Latvia

${ }^{4}$ University of Zagreb, Trg Republike Hrvatske 14, 10000 Zagreb, Croatia

${ }^{5}$ University of Economics in Bratislava, Dolnozemská cesta 1/b, 85235 Bratislava, Slovak Republic

${ }^{6}$ University of Economics, Prague, nám. W. Churchilla 1938/4, 13067 Praha 3, Czech Republic

E-mails: ${ }^{1}$ rasa.subaciene@evaf.vu.lt; ${ }^{2}$ lehte.alver@ttu.ee; ${ }^{3}$ inta.bruna@lu.lv; ${ }^{4}$ mhladika@efzg.hr; ${ }^{5}$ dasa.mokosova@euba.sk;

6 jan.molin@vse.cz

Received 10 March 2018; accepted 20 March 2018; published 30 September 2018

\begin{abstract}
Accounting forms a significant part of information on any enterprise and plays the most important role in different levels of enterprise' management as well as in country's. Accounting information is used by various information users, whose decisions may influence various spheres: from performance of enterprises to proceeding the state policy. Its role increased recently under conditions of modern global and competitive market economy, and will be increasing in the future. Importance of accounting information usage highlights the need of appropriate formation of such information. And accounting regulation plays the main role in the process of formation and presentation of accounting information as it determines requirements for accounting methodology, information performed in the single set of financial statements or consolidated financial statements. The purpose of the research is to evaluate evolution of accounting regulation for the period 1990 - 2017 and distinguish accounting regulation evolution phases and factors, which influenced development of the phases. Six countries, which are members of the European Union - the Republic of Croatia, the Czech Republic, the Republic of
\end{abstract}


The International Journal

ENTREPRENEURSHIP AND SUSTAINABILITY ISSUES

ISSN 2345-0282 (online) http://jssidoi.org/jesi/

2018 Volume 6 Number 1 (September)

http://doi.org/10.9770/jesi.2018.6.1(11)

Estonia, the Republic of Latvia, the Republic of Lithuania and the Slovak Republic - were chosen for the evaluation of accounting evolution. For the research were used legislation analysis, systematisation, inductive and deductive, comparison and summary of information methods. Research results show, that evolution of accounting regulation in analysed countries may be distinguished in four general phases. The period of evolution started at the beginning of nineties (1990-1992) when the countries transformed from a central planned economy to market economy, this phase was followed by other phases (1993-2001-2005), when laws on accounting and additional legislation were issued. Accounting regulation evolution phase for alignment accounting legislation with Fourth and Seventh EU Directives started from 2002/2006 and the phase of the compliance with requirements of Directive 2013/34/EU of the European Parliament and of the Council of 26 June 2013, which started in all analysed countries in 2016, except Slovakia - in 2014, completes the accounting regulation evolution period till present.

Keywords: accounting; development of accounting; accounting regulation; the Republic of Croatia; the Czech Republic; the Republic of Estonia, the Republic of Latvia; the Republic of Lithuania; the Slovak Republic

Reference to this paper should be made as follows: Subačienė, R.; Alver, L.: Brūna, I.; Hladika, M.; Mokošová, D.; Molín, J. 2018. Evaluation of accounting regulation evolution in selected countries, Entrepreneurship and Sustainability Issues 6(1): 140-175. http://doi.org/10.9770/jesi.2018.6.1(11)

JEL Classifications: M41

\section{Introduction}

Accounting forms a significant part of information on any enterprise and plays the most important role in different levels of enterprise' management as well as in country's. Accounting information is used by various information users, whose decisions may influence various spheres: from performance of enterprises to proceeding the state policy. Its role increased recently under conditions of modern global and competitive market economy, and will be increasing in the future (Strichko, 2013; Paseková et al., 2018, Kunitsyna et al., 2018). Importance of accounting information usage highlights the need of appropriate formation of such information. And accounting regulation plays the main role in the process of formation and presentation of accounting information as it determines requirements for accounting methodology, information performed in the single set of financial statements or consolidated financial statements.

The purpose of the research is to evaluate evolution of accounting regulation for the period $1990-2017$ and distinguish accounting regulation evolution phases and factors, which influenced development of the phases. Six countries, which are members of the European Union - the Republic of Croatia, the Czech Republic, the Republic of Estonia, the Republic of Latvia, the Republic of Lithuania and the Slovak Republic - were chosen for the evolution of accounting evolution. For the research all available countries, which joined European Union from 1the of May, 2004 and The Republic of Croatia, which became a member of EU at latest terms, were selected. For the research were used legislation analysis, inductive and deductive, information's systematisation, comparison and summary methods.

\section{Research methodology}

The research methodology of evaluation of accounting regulation evolution is presented in the Figure 1. 


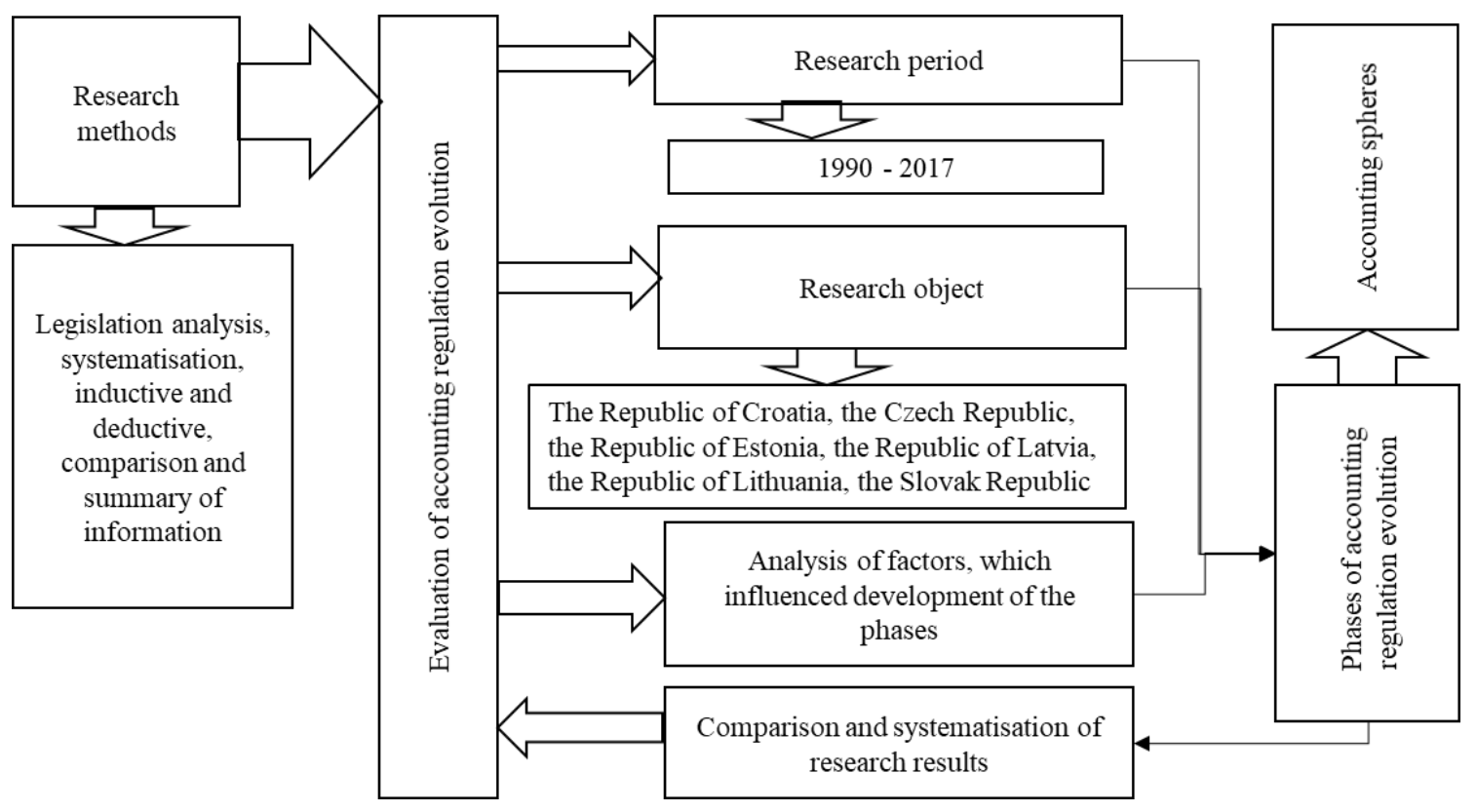

Fig. 1. Research methodology

As Figure 1 shows the research methodology consists of several stages. Research period includes 1990-2017 years. For the research object were chosen six countries: The Republic of Croatia, the Czech Republic, The Republic of Estonia, the Republic of Latvia, the Republic of Lithuania, the Slovak Republic. The Republic of Estonia, the Republic of Latvia, the Republic of Lithuania were chosen for the research as these countries have quite similar economic, political and culture background, and started their development at the same conditions. The same reasons were applied for the Czech Republic and the Slovak Republic. All mentioned countries are members of the European Union from 1 May 2004. The Republic of Croatia joined the European Union on 1 July 2013 and was chosen for research purpose as indicator of hypothesis approvement. Under the research phases of accounting regulation evolution by accounting spheres are distinguished, factors, which made impact for development of phases, are analysed, hypothesis, that newly formed, independent European countries accounting development depends on accession to the European Union was raised, and comparison and systematisation of research results are presented.

\section{Evolution of accounting regulation in Croatia}

Since Croatia gained its independence in 1991 (October 8th), a reform of ownership and economy has started. Reform processes required significant changes of legal and institutional framework in order to satisfy the transition from social (state) to a private ownership, and for the purpose of development of democracy and free market economy system. In that new business environment most social (state) business entities turned into joinstock companies in a private ownership. Furthermore, many new small and medium-sized companies were established in that period. Inherited institutional infrastructure couldn't satisfy requirements for conducting a business in that new business environment and it required significant changes and modifications. In whole institutional infrastructure, significant part concern to the accounting regulation. New accounting regulation has to be adjusted to a private ownership and financial markets. 


\section{The International Journal}

ENTREPRENEURSHIP AND SUSTAINABILITY ISSUES

ISSN 2345-0282 (online) http://jssidoi.org/jesi/ 2018 Volume 6 Number 1 (September) http://doi.org/10.9770/jesi.2018.6.1(11)

First phase of accounting regulations includes the period from gaining the independency till the end of 1992. In that period accounting was regulated by the Law on Accounting (1991). Actually, this law was the last Law on Accounting enacted and implemented in former Yugoslavia in 1989. Key characteristic of the accounting system in that period was the singular system of financial reporting (Gulin et al., 2003). That means that financial statements of all business entities have to be submitted to the state institution Social bookkeeping service (Služba društvenog knjigovodstva) which has the role of proprietary authorities and oversight. The evidence of business transactions was based on double-entry bookkeeping and on prescribed chart of accounts. Such requirements ensured unified financial statements, and the indicator of business success was profit which was determined as a difference between total revenues and total expenses. Business entities submitted their financial statements into court register. This phase of accounting regulations is marked with insufficient legislation in order to establish quality accounting system, and the comprehensive framework for transition from social to market economy was not developed.

Second phase of accounting regulations started in 1993 with the implementation of first Law on Accounting (1992) that has been prepared and adopted in independent Croatia (see Table 1). This Law on Accounting didn't prescribed chart of accounts, and it permitted each business entity to develop its own chart of accounts in accordance with its specific needs. The content (elements) of financial statements (only balance sheet and profit and loss account) for all business entities (for entrepreneurs, banks and other financial institutions, insurance companies) was prescribed and it was aligned with the Fourth (78/660/EEC) EU directive. The aim of financial reporting was to present faithful and relevant information for all users of financial statements. Crucial change that was implemented through this Law on Accounting includes the implementation of International Accounting Standards for all (listed and non-listed) entities. Furthermore, this Law introduced the implementation of dual system of financial reporting (Gulin et al., 2003). That means, business entities prepared one set of financial statements for external users (such as shareholders, creditors), and the other set of financial statements for state institutions (such as tax authorities). The obligation to prepare the consolidated financial statements was prescribed by this Law on Accounting. Comparing the previous accounting system and procedures with this one it can be seen significant switch in order to strengthen the quality of financial reporting and use of accounting information for all users. Furthermore, by this Law has been established the Croatian Board for Accounting and Accounting Standards. The purpose of this Board was to monitor, coordinate and explain the implementation of International Accounting Standards. This phase of accounting regulations ended at the end of 2005. It is important to highlight that during this phase the Company Law (1993) was enacted (and it is valid till today, but it was amended 12 times). In Company Law was included the provisions on responsibility for conduction of financial books, for preparation of financial statements and for decision making on profit use. The Law on registry of annual financial statements (2003) prescribed the obligation for all business entities that have to pay profit tax to submit their financial statements into Registry which is conducted by Financial agency.

Next phase of accounting regulations is developed in accordance with the integration processes of Croatia into the European Union. This phase started with the implementation of second Law on Accounting (2005). The main changes that were implemented by this Law include the new classification of business entities (small, medium and large), new (longer) deadlines for keeping the financial books and bookkeeping documents, and the new set of annual financial statements. Oversight authorities for business entities (entrepreneurs, banks, insurance companies etc.) are authorized to prescribe the content and structure of financial statements for certain type of business entity. The content and structure of financial statements for entrepreneurs are defined in Ordinance on the structure and content of annual financial statements (2008). Since 1 January 2006, large companies and all listed companies have to apply International Financial Reporting Standards (IFRS). All other companies (small and medium) can apply International Financial Reporting Standards or they can apply new national accounting standards which are called Croatian Financial Reporting Standards (CFRS). The Board for Financial Reporting Standards was established by this Law on Accounting. This Board was accredited for development of CFRS. 
The International Journal

ENTREPRENEURSHIP AND SUSTAINABILITY ISSUES

ISSN 2345-0282 (online) http://jssidoi.org/jesi/

2018 Volume 6 Number 1 (September)

http://doi.org/10.9770/jesi.2018.6.1(11)

Also, with the implementation of this Law on Accounting the Croatian Board for Accounting and Accounting Standards has ceased to exist. This accounting regulation was based on EU directives (Fourth and Seventh) and on IFRS, and it was aligned with the accounting regulation of other developed EU countries at that time.

New step in this phase can be determined with the implementation of Croatian Financial Reporting Standards (1 January, 2008). Also, on 1 January 2008 started the application of new Law on Accounting (2007). The CFRS are developed by the Board for Financial Reporting Standards and till today are developed 17 CFRS. The main criticism of CFRS was the fact that they have to be in accordance with IFRS which are too complicated for small and medium sized companies. In that Law on accounting were defined the groups of entrepreneurs, accounting procedures, the obligation for preparation of annual financial statements and consolidated financial statements as well as the obligation to prepare annual report for certain types of entrepreneurs. Furthermore, the obligation for public announcement of annual financial statements and consolidated financial statements has been prescribed in this Law on Accounting as well as the submission of statistical data to Financial agency.

Significant impact on changes in accounting regulation in Croatia has the Directive 2013/34/EU which main aim was to simplify the accounting regulation for micro entities. In accordance with this new Directive and new requirements, the accounting regulation in Croatia has been changed again, and the new Law on Accounting (2015) is applying from January 1, 2016. In this Law on Accounting are defined new classification of entrepreneurs (micro, small, medium and large) and groups of entrepreneurs, accounting organization, set of financial statements for certain types of entrepreneurs, the obligation for preparation of consolidated financial statements, preparation of annual report, public announcement and the responsibility for public announcement, the Registry of financial statements which is carrying on by Financial Agency as well as the oversight over the accounting affairs in entrepreneurs (Ministry of Finance).

Table 1. Main legal acts for regulation of accounting in Croatia, 1991-2017

\begin{tabular}{|c|c|c|c|c|c|c|c|c|c|}
\hline \multirow[b]{3}{*}{ 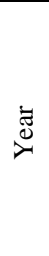 } & \multirow[b]{3}{*}{$\begin{array}{c}\text { issue } \\
\text { date }\end{array}$} & \multirow[b]{3}{*}{$\begin{array}{l}\text { effect } \\
\text { date }\end{array}$} & \multicolumn{2}{|r|}{ Legislation } & \multicolumn{5}{|c|}{ Accounting regulation spheres } \\
\hline & & & & & \multirow[b]{2}{*}{ 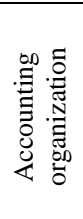 } & \multirow[b]{2}{*}{ 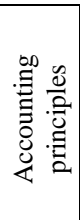 } & \multicolumn{2}{|c|}{ Reporting } & \multirow[b]{2}{*}{ 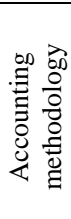 } \\
\hline & & & $\begin{array}{c}\text { cancel } \\
\text { ation } \\
\text { date }\end{array}$ & type and title & & & 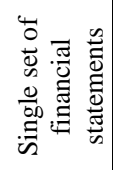 & 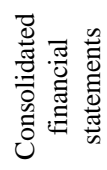 & \\
\hline $\bar{\Omega}$ & $\begin{array}{c}08.10 . \\
1991\end{array}$ & $\begin{array}{c}08.10 . \\
1991\end{array}$ & $\begin{array}{l}31.12 . \\
1992 .\end{array}$ & $\begin{array}{l}\text { Law on Accounting, 1991, Official Gazette, No. 53/91, } \\
\text { 33/92. }\end{array}$ & $\mathrm{X}$ & & $\mathrm{X}$ & & $\mathrm{X}$ \\
\hline$\stackrel{2}{2}$ & $\begin{array}{l}30.12 . \\
1992 .\end{array}$ & $\begin{array}{l}01.01 . \\
1993 .\end{array}$ & $\begin{array}{l}31.12 . \\
2005 .\end{array}$ & Law on Accounting, 1992, Official Gazette, No. 90/92. & $\mathrm{X}$ & $\mathrm{X}$ & $\mathrm{X}$ & $\mathrm{X}$ & $\mathrm{X}$ \\
\hline 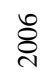 & $\begin{array}{l}12.12 . \\
2005 .\end{array}$ & $\begin{array}{l}01.01 . \\
2006 .\end{array}$ & $\begin{array}{l}31.12 . \\
2007 .\end{array}$ & $\begin{array}{l}\text { Law on Accounting, 2005, Official Gazette, No. } \\
146 / 05 \text {. }\end{array}$ & $\mathrm{X}$ & $\mathrm{X}$ & $\mathrm{X}$ & $\mathrm{X}$ & $\mathrm{X}$ \\
\hline 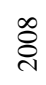 & $\begin{array}{l}24.10 . \\
2007 .\end{array}$ & $\begin{array}{l}01.01 . \\
2008 .\end{array}$ & $\begin{array}{l}31.12 . \\
2015 .\end{array}$ & $\begin{array}{l}\text { Law on Accounting, 2007, Official Gazette, No. } \\
\text { 109/07, 54/13. }\end{array}$ & $\mathrm{X}$ & $\mathrm{X}$ & $\mathrm{X}$ & $\mathrm{X}$ & $\mathrm{X}$ \\
\hline$\stackrel{\text { ¿ }}{\circ}$ & $\begin{array}{l}02.04 . \\
2008 .\end{array}$ & $\begin{array}{l}10.04 . \\
2008 .\end{array}$ & $\begin{array}{l}31.12 . \\
2015 .\end{array}$ & $\begin{array}{l}\text { Ordinance on the structure and content of annual } \\
\text { financial statements, 2008, Official Gazette, No. 38/08, } \\
12 / 09,130 / 10 \text {. }\end{array}$ & & & $\mathrm{X}$ & $\mathrm{X}$ & \\
\hline$\stackrel{2}{\stackrel{2}{2}}$ & $\begin{array}{l}17.07 . \\
2015 .\end{array}$ & $\begin{array}{l}01.01 . \\
2016 .\end{array}$ & & $\begin{array}{l}\text { Law on Accounting, 2015, Official Gazette, No. } 78 / 15 \text {, } \\
134 / 15,120 / 16 \text {. }\end{array}$ & $\mathrm{X}$ & $\mathrm{X}$ & $\mathrm{X}$ & $\mathrm{X}$ & $\mathrm{X}$ \\
\hline
\end{tabular}


The International Journal

ENTREPRENEURSHIP AND SUSTAINABILITY ISSUES

ISSN 2345-0282 (online) http://jssidoi.org/jesi/

2018 Volume 6 Number 1 (September)

http://doi.org/10.9770/jesi.2018.6.1(11)

\begin{tabular}{|c|c|c|c|c|c|c|c|c|c|}
\hline \multirow[b]{3}{*}{ 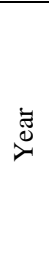 } & \multicolumn{4}{|r|}{ Legislation } & \multicolumn{5}{|c|}{ Accounting regulation spheres } \\
\hline & \multirow[b]{2}{*}{$\begin{array}{l}\text { issue } \\
\text { date }\end{array}$} & \multirow[b]{2}{*}{$\begin{array}{l}\text { effect } \\
\text { date }\end{array}$} & \multirow[b]{2}{*}{$\begin{array}{c}\text { cancel } \\
\text { ation } \\
\text { date }\end{array}$} & \multirow[b]{2}{*}{ type and title } & \multirow[b]{2}{*}{ 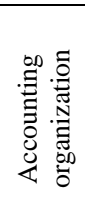 } & \multirow[b]{2}{*}{ 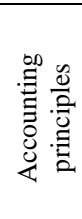 } & \multicolumn{2}{|c|}{ Reporting } & \multirow[b]{2}{*}{ 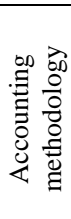 } \\
\hline & & & & & & & 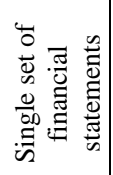 & 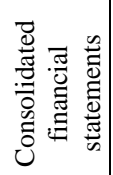 & \\
\hline 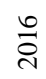 & $\begin{array}{l}20.10 . \\
2016 .\end{array}$ & $\begin{array}{l}28.10 . \\
2016 .\end{array}$ & & $\begin{array}{l}\text { Ordinance on the structure and content of annual } \\
\text { financial statements, 2016, Official Gazette, No. 95/16. }\end{array}$ & & & $X$ & $\mathrm{X}$ & \\
\hline
\end{tabular}

Source: Composed by authors according to references presented in the Table

During the observed period (1990-2017) significant changes has occurred in the public sector accounting. Intensive developing processes enclosed the transition from the application of cash basis to the application of accrual basis of accounting in the public sector accounting. The aim of reform processes was to harmonize regulatory framework in Croatia with international and European standards of financial and statistical reporting in order to include Croatia into European financial and economic processes (Hladika, 2013). First years after Croatia gained its independence the most important changes include the development of new institutional framework. First phase includes the period from 1991 to 1993, and the regulatory framework was taken from former Yugoslavia. In 1994, Croatia adopted its first Budget Law (1994). Accounting system in public sector according to this Budget Law was based on cash basis of accounting, the application of double-entry bookkeeping and unique chart of accounts for all public sector entities. Furthermore, by this Budget Law the state treasury was introduced and the classification systems were harmonized significantly with international standards of state financial statistics (GFS 1986). Next phase of development of public sector accounting started in 2002 when the cash basis of accounting in public sector accounting has been abandon and the modified accrual basis of accounting has been introduced. New Budget Law (2003) applied from June 1, 2003. This Budget Law regulated planning, the preparation of budget, management of assets and debts, management of public debt, budgetary relationships in public sector, accounting and financial reporting, and internal and budgetary oversight. International system of financial classification (GFS 2001) has been implemented in budgetary system by this Budget Law. Some changes were introduced in public sector accounting in following Budget Law (2008). European system of financial classification (ESA 2010) has been introduced by this Budget Law. Accounting organization, accounting principles and accounting methodology are defined in Ordinance for public sector accounting and chart of accounts (2014). The structure and content of financial statements of public sector entities are defined in Ordinance for financial reporting in public sector accounting (2015).

Till today, in Croatia are not developed national accounting standards for public sector entities but the suggestion is to apply International Public Sector Accounting Standards (IPSAS). Current state of development of public sector accounting indicates that in Croatia have to be undertaken many activities in order to introduce full accrual basis of accounting in the future.

\section{Evolution of accounting regulation in the Czech Republic}

Before we start dealing with the analysis of accounting regulation in the Czech Republic, it is necessary to put the development of the Czech Republic into historic context. The Czech Republic was a unified state together with the Slovak Republic until the end of 1992 (Czechoslovakia). Czechoslovakia was formed in 1918 and it underwent rather turbulent developments. After the Second World War, the communist party assumed power and it cast us in a totalitarian regime for more than 40 years. The economic system was corresponding: the Czechoslovak Socialist Republic (the official name back then) applied a central planned economy, which affected the relevant accounting regulation and the rules applied. Financial statements - if they were actually compiled - 
The International Journal

ENTREPRENEURSHIP AND SUSTAINABILITY ISSUES

ISSN 2345-0282 (online) http://jssidoi.org/jesi/

2018 Volume 6 Number 1 (September)

http://doi.org/10.9770/jesi.2018.6.1(11)

had a totally different role than today. Companies presented expenses by nature, finished goods ("changes in inventories of finished goods" to be precise) were recognized as revenue. The legal framework for keeping the books was given by an act from 1971 - Act No. 21/1971 Coll., on Uniform System of Social-Economic Information.

"The Velvet Revolution", which refers to a period of political changes that resulted in the fall of communism and transition to democracy, took place in Czechoslovakia in 1989. It was linked with a change toward free-market economy. This was reflected in many legal industries, including accounting regulation. Technically speaking, the first (and immediate) action in the sphere of legal regulation of accounting was Decree No. 23/1990 Coll., on Accounting, issued by the Federal Ministry of Finance on the basis of the above stated act on Uniform System of Social-Economic Information of 1971 that came to force on 1 March 1990. This Decree defined that books were to be kept in two accounting systems: double-entry and single-entry systems. Nevertheless, the enactment of the Decree concerned accounting organization rather than definition of accounting principles and methods.

The actual reform of accounting regulation, which followed the reform of private law (Act No. 513/1991 Coll., the Commercial Code, entered in force as of 1 January 1992), occurred in 1991 when Act No. 563/1991 Coll., on Accounting (hereinafter referred to as the "Act on Accounting") was approved. The Act on Accounting, before any amendments, defined two accounting systems: the system of double entry bookkeeping and the system on the basis of cash receipts and disbursements (single-entry accounting system), and it also defined basic accounting principles, the duty to compile a single set of financial statements as well as the duty to compile consolidated financial statements, which was new at the time. It was a new legal regulation that has remained in force in the Czech Republic up to the present (even after the Czech Republic and the Slovak Republic split on 1 January 1993).

With respect to the fact that the Act on Accounting did not define (and doesn't define even at present) specific accounting methods, arrangement of items in annual financial statements or other areas, it anticipated the approval of implementing regulations by the Ministry of Finance. Therefore, a series of decrees was issued and applied by the Federal Ministry of Finance, of which the most important one was Decree No. V/20 100/1992 of 15 July 1992 laying down the framework for the chart of accounts and details of the accounting procedures for entrepreneurs. Its measures were substituted with new ones in the course of time - see the Table 2 below.

Quite a significant milestone in accounting regulation came in 2002 when the Act on Accounting was amended: this amendment defined more accurately defined accounting principles and it is referred to as the „Big Amendment" (Huleš, Jeřábek, 2001). Following this amendment, the Ministry of Finance of the Czech Republic issued a set of accounting regulations for different types of accounting units. These regulations were (in contrast with the previous ones) issued as subordinate legislation (implementing) statutory instrument and they entered in force in 2003. See their complete list in the Table 2 below.

The Ministry of Finance of the Czech Republic issued accounting standards describing accounting methods for different accounting units in more detail. These standards entered in force in 2004. Therefore, we may conclude by saying that there has been as three-level accounting regulation in the Czech Republic since 2004. The basic legal regulation is the Act on Accounting that defines, in particular, the scope of accounting units, accounting principles, accounting organization, requirements for a single set of financial statements and consolidated financial statements, requirements for auditing and principles of accounting methodology. The Ministry of Finance of the Czech Republic has also issued decrees for different types of accounting units that have the function of implementing legal regulation: they describe and define accounting methods in a greater detail and define how items in financial statements are to be arranged and marked. The third level consists in Czech 
The International Journal

ENTREPRENEURSHIP AND SUSTAINABILITY ISSUES

ISSN 2345-0282 (online) http://jssidoi.org/jesi/

2018 Volume 6 Number 1 (September)

http://doi.org/10.9770/jesi.2018.6.1(11)

accounting standards (that are not considered a legal regulation) that are issued on the basis of authorization in the Act on Accounting and they describe accounting methods and processes in a greater detail.

Since 2004, the Act on Accounting has been amended rather greatly and it has brought along a lot of system changes. These included, in particular, cancellation of the legal regulation of single-entry accounting that could be maintained by certain natural persons (entrepreneurs) and smaller non-profit entities. A new system has been created for natural persons. It is similar to single-entry accounting, which is a system on the basis of cash receipts and disbursements. However, this system is not considered an accounting regulation, but it is regulated by the tax law and referred to as tax record keeping (this is, in fact, only for the purpose of defining the personal income tax base). Another intention of the change was to cancel the single-entry accounting system also for legal entities, with the view of all legal entities switching to double-entry accounting. This wasn't accomplished, as deadlines for smaller non-profit entities were by which they were required to switch to double-entry accounting were postponed many times until 2016 when the Act on Accounting was amended by legal regulation stipulating the possibility of accounting in a single-entry system.

With respect to the fact that the Czech Republic has been a member of the European Union since 1 May 2004, the duty to use International Financial Reporting Standards in accordance with Resolution No. 1606/2002 of the European Parliament and of the Council of 19 July 2002, on the application of the International Financial Reporting Standards, was introduced as of that date. The Czech Republic has decided to introduce the duty to apply the IFRS also on the single set of financial statements, whereas there was first the duty to apply the IFRS to listed companies. As of 1 January 2011, the scope of subjects that may apply IFRS was extended and concerned also companies whose stocks are not traded on the regulated market and entities that are members of a group of companies that compile their consolidated financial statements according to the IFRS. Nevertheless, it should be pointed out that IFRS (obligatory as well as voluntary) cannot be applied for the purpose of determining the corporate income tax base. In other words, entities using the IFRS have to determine their income tax base from the profit according to Czech accounting regulations (like in case of entities that use Czech accounting regulations for financial statements - Skálová, 2017), which is subsequently adjusted by modifying certain items that significantly affect corporate income tax revenues in the Czech Republic (Mejzlík, Vítek, Roe, 2013). At present, there are discussions in the Czech Republic, whether the profit according to IFRS could be used as the income tax base in future (Procházka, 2013).

Another rather revolutionary change to Czech accounting regulations entered in force in 2010, when "reform in accounting of state administration" (state administration, state-funded organizations) was introduced. Health insurance houses and some other organizations introduced similar methodological rules that are applied by common business entities. The aim was to find out more accurate and relevant information about the financial position of those accounting units. The top priority was the possibility to compile a (consolidated) financial statements for the entire Czech Republic. A "consolidation decree" containing accounting methodology for consolidation was issued for this purpose in 2014. 
Table 2. Main legal acts for regulation of accounting in the Czech Republic, 1990-2017

\begin{tabular}{|c|c|c|c|c|c|c|c|c|c|}
\hline \multirow[b]{3}{*}{ 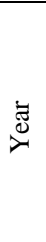 } & \multirow[b]{3}{*}{$\begin{array}{l}\text { issue } \\
\text { date }\end{array}$} & \multirow[b]{3}{*}{$\begin{array}{l}\text { effect } \\
\text { date }\end{array}$} & \multicolumn{2}{|r|}{ Legislation } & \multicolumn{5}{|c|}{ Accounting regulation spheres } \\
\hline & & & & & \multirow[b]{2}{*}{ 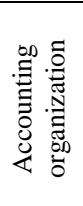 } & \multirow[b]{2}{*}{ 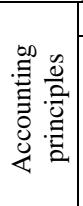 } & \multicolumn{2}{|c|}{ Reporting } & \multirow[b]{2}{*}{ 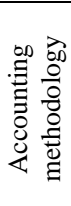 } \\
\hline & & & $\begin{array}{l}\text { cancel } \\
\text { ation } \\
\text { date }\end{array}$ & type and title & & & 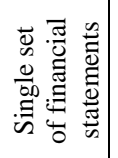 & 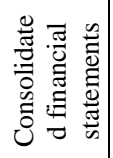 & \\
\hline よ & $\begin{array}{c}31.01 . \\
1990\end{array}$ & $\begin{array}{c}01.03 . \\
1990\end{array}$ & $\begin{array}{c}31.12 . \\
1991\end{array}$ & $\begin{array}{l}\text { Decree of the Federal Ministry of Finance of the } \\
\text { Czechoslovakia Republic No. 23/1990 Coll., on } \\
\text { Accounting }\end{array}$ & $\mathrm{X}$ & & $\mathrm{X}$ & & \\
\hline $\bar{\sigma}$ & $\begin{array}{c}12.12 . \\
1991\end{array}$ & $\begin{array}{c}01.01 . \\
1992\end{array}$ & & Act No. 563/1991 Coll. on Accounting & $\mathrm{X}$ & $\mathrm{X}$ & $\mathrm{X}$ & $\mathrm{X}$ & $\mathrm{X}$ \\
\hline ๙ू & $\begin{array}{c}15.07 . \\
1992\end{array}$ & $\begin{array}{c}01.01 . \\
1993\end{array}$ & $\begin{array}{c}31.12 . \\
2001\end{array}$ & $\begin{array}{l}\text { Decree No. V/20 100/1992 of } 15 \text { July } 1992 \text { laying } \\
\text { down the framework for the chart of accounts and } \\
\text { details of the accounting procedures for entrepreneurs }\end{array}$ & & & & & $\mathrm{X}$ \\
\hline$\delta$ & $\begin{array}{c}23.12 . \\
1992\end{array}$ & $\begin{array}{c}01.01 . \\
1993\end{array}$ & $\begin{array}{c}31.12 . \\
2000\end{array}$ & $\begin{array}{l}\text { Decree No. V/1-31 370/1992 of } 23 \text { December } 1992 \\
\text { laying down details of the accounting procedures for } \\
\text { sole traders carrying out business activities or other } \\
\text { activities generating income under the basis of cash } \\
\text { receipts and disbursements }\end{array}$ & & & $\mathrm{X}$ & & $\mathrm{X}$ \\
\hline ๙ั & $\begin{array}{c}29.12 . \\
1992\end{array}$ & $\begin{array}{c}01.01 . \\
1993\end{array}$ & $\begin{array}{c}31.12 . \\
1995\end{array}$ & $\begin{array}{l}\text { Decree No. V/1- } 31388 / 1992 \text { of } 29 \text { December } 1992 \\
\text { laying down the structure and content of items of the } \\
\text { balance sheet and the income statement for } \\
\text { entrepreneurs }\end{array}$ & & & $\mathrm{X}$ & & $\mathrm{X}$ \\
\hline$\stackrel{2}{\Omega}$ & $\begin{array}{c}21.12 . \\
1995\end{array}$ & $\begin{array}{c}01.01 . \\
1996\end{array}$ & $\begin{array}{c}31.12 . \\
2001\end{array}$ & $\begin{array}{l}\text { Decree No. } 281 / 71701 / 95 \text { of } 21 \text { December } 1995 \text { laying } \\
\text { down the content of financial statements for } \\
\text { entrepreneurs }\end{array}$ & & & $\mathrm{X}$ & & $\mathrm{X}$ \\
\hline ষ্ণ & $\begin{array}{c}10.11 \\
2000\end{array}$ & $\begin{array}{c}01.01 . \\
2001\end{array}$ & $\begin{array}{c}31.12 . \\
2002\end{array}$ & $\begin{array}{l}\text { Decree No. } 281,283 / 77411 / 2000 \text { of } 10 \text { November } \\
2000 \text { laying down details of the accounting procedures } \\
\text { for accounting units under the basis of cash receipts and } \\
\text { disbursements }\end{array}$ & & & $\mathrm{X}$ & & $\mathrm{X}$ \\
\hline ఠ్ & $\begin{array}{c}14.11 \\
2001\end{array}$ & $\begin{array}{c}01.01 . \\
2002\end{array}$ & $\begin{array}{c}31.12 . \\
2002\end{array}$ & $\begin{array}{l}\text { Decree No. } 281 / 89759 / 2001 \text { of } 14 \text { November } 2001 \\
\text { laying down the framework for the chart of accounts } \\
\text { and details of the accounting procedures for } \\
\text { entrepreneurs }\end{array}$ & & & & & $\mathrm{X}$ \\
\hline$\overline{8}$ & $\begin{array}{c}14.12 . \\
2001\end{array}$ & $\begin{array}{c}01.01 . \\
2002\end{array}$ & $\begin{array}{c}31.12 . \\
2002\end{array}$ & $\begin{array}{l}\text { Decree No. 281/97 417/2001 of } 14 \text { December } 2001 \\
\text { laying down the content of financial statements for } \\
\text { entrepreneurs }\end{array}$ & & & $\mathrm{X}$ & & $\mathrm{X}$ \\
\hline ఠิ & $\begin{array}{c}06.11 \\
2002\end{array}$ & $\begin{array}{c}01.01 . \\
2003\end{array}$ & & $\begin{array}{l}\text { Decree No. 500/2002 Coll. implementing some } \\
\text { provisions of Act No. 563/1991 Coll., on Accounting, } \\
\text { as amended, for accounting units that are entrepreneurs } \\
\text { using the double-entry accounting system }\end{array}$ & & & $\mathrm{X}$ & $\mathrm{X}$ & $\mathrm{X}$ \\
\hline ఠ̊ & $\begin{array}{c}06.11 . \\
2002\end{array}$ & $\begin{array}{c}01.01 . \\
2003\end{array}$ & & $\begin{array}{l}\text { Decree No. 501/2002 Coll. implementing some } \\
\text { provisions of Act No. 563/1991 Coll., on Accounting, } \\
\text { as amended, for accounting units that are banks and } \\
\text { other financial institutions }\end{array}$ & & & $\mathrm{X}$ & $\mathrm{X}$ & $\mathrm{X}$ \\
\hline రి & $\begin{array}{c}06.11 \\
2002\end{array}$ & $\begin{array}{c}01.01 . \\
2003\end{array}$ & & $\begin{array}{l}\text { Decree No. 502/2002 Coll. implementing some } \\
\text { provisions of Act No . 563/1991 Coll., on Accounting, } \\
\text { as amended, for accounting units that are insurance } \\
\text { companies }\end{array}$ & & & $\mathrm{X}$ & $\mathrm{X}$ & $\mathrm{X}$ \\
\hline ఠิ & $\begin{array}{c}06.11 \\
2002\end{array}$ & $\begin{array}{c}01.01 . \\
2003\end{array}$ & & $\begin{array}{l}\text { Decree No. 503/2002 Coll. implementing some } \\
\text { provisions of Act No. 563/1991 Coll., on Accounting, } \\
\text { as amended, for health insurance companies }\end{array}$ & & & $\mathrm{X}$ & & $\mathrm{X}$ \\
\hline
\end{tabular}




\begin{tabular}{|c|c|c|c|c|c|c|c|}
\hline ఫ్ & $\begin{array}{c}06.11 . \\
2002\end{array}$ & $\begin{array}{c}01.01 . \\
2003\end{array}$ & & $\begin{array}{l}\text { Decree No. 504/2002 Coll. implementing some } \\
\text { provisions of Act No. 563/1991 Sb., on Accounting, as } \\
\text { amended, for accounting units whose objects clause is } \\
\text { not business, providing they use the double-entry } \\
\text { accounting system }\end{array}$ & $X$ & & $X$ \\
\hline ర్సి & $\begin{array}{c}06.11 . \\
2002\end{array}$ & $\begin{array}{c}01.01 . \\
2003\end{array}$ & $\begin{array}{c}31.12 . \\
2005\end{array}$ & $\begin{array}{l}\text { Decree No. 506/2002 Coll. implementing some } \\
\text { provisions of Act No. 563/1991 Coll., on Accounting, } \\
\text { as amended, for the following accounting units: } \\
\text { National Property Fund of the Czech Republic and } \\
\text { National Land Fund of the Czech Republic }\end{array}$ & $X$ & & $\mathrm{X}$ \\
\hline ఫ్రి & $\begin{array}{c}06.11 . \\
2002\end{array}$ & $\begin{array}{c}01.01 . \\
2003\end{array}$ & $\begin{array}{c}31.12 . \\
2003\end{array}$ & $\begin{array}{l}\text { Decree No. 507/2002 Coll. implementing some } \\
\text { provisions of Act No. 563/1991 Coll., on Accounting, } \\
\text { as amended, for accounting units using the single-entry } \\
\text { system }\end{array}$ & $X$ & & $X$ \\
\hline ڤ્ণે & $\begin{array}{c}11.11 . \\
2009\end{array}$ & $\begin{array}{c}01.01 . \\
2010\end{array}$ & & $\begin{array}{l}\text { Decree No. 410/2009 Coll. implementing some } \\
\text { provisions of Act No. 563/1991 Coll., on Accounting, } \\
\text { as amended, for selected accounting units (state } \\
\text { administration) }\end{array}$ & $X$ & & $X$ \\
\hline$\stackrel{\Delta}{\stackrel{\Delta}{\sim}}$ & $\begin{array}{c}11.12 . \\
2014\end{array}$ & $\begin{array}{c}01.01 . \\
2015\end{array}$ & & $\begin{array}{l}\text { Decree No. 312/2014 Coll. on conditions for compiling } \\
\text { accounting statements for the Czech Republic (the } \\
\text { consolidation degree of the state) }\end{array}$ & & $X$ & $\mathrm{X}$ \\
\hline$\frac{n}{\tilde{d}}$ & $\begin{array}{l}25.11 \text {. } \\
2015\end{array}$ & $\begin{array}{c}01.01 . \\
2016\end{array}$ & & $\begin{array}{l}\text { Decree No. 325/2015 Coll. implementing some } \\
\text { provisions of Act No. 563/1991 Coll., on Accounting, } \\
\text { as amended, for accounting units using the single-entry } \\
\text { accounting }\end{array}$ & $X$ & & $\mathrm{X}$ \\
\hline
\end{tabular}

Source: Composed by authors according to references presented in the Table

As the Table 2 presents, latest important amendment to Czech accounting regulations resulted from the duty to transpose Directive 2013/34/EU of the European Parliament and of the Council of 26 June 2013 on the annual financial statements, consolidated financial statements and related reports of certain types of undertakings, the purpose of which was to decrease administrative duties for micro and small accounting units (Žárová, 2013). Thus, a vast amendment to Czech accounting regulations reflecting these changes entered in force on 1 January 2016.

\section{Evolution of accounting regulation in the Republic of Estonia}

Half a century accounting in Estonia was part of the Soviet accounting system. The first step on the way to change the situation was made in 1990, while Estonia remained, albeit reluctantly, a constituent republic of the USSR. On July 6, 1990, the Regulation of Accounting (hereinafter the Regulation) was adopted by the National Government and came into force on January 1, 1991 (see Table 3). It is of special interest because it was the first measure adopted in any of the constituent republics of the USSR to mark a departure from the path of the Soviet accounting evolution. As pointed out by Bailey (Bailey et al., 1995), this event marked the beginning of the spread of accounting disharmony within the territories comprising the USSR. It was really an "accounting step" on the transition from command economy to market economy. The declared purpose of the Regulation was to bring about the organization of accounting in the conditions of a market economy. Real accounting continued to be perceived as properly subject to centralized prescription and its primary purpose the meeting of the needs of the central authorities of Estonia (Statistics Bureau, Tax Department) and not, as hitherto, those of the USSR (Alver J., Alver L., 2008). 
In 1991, the Estonian Accounting Board took the responsibility for the development of accounting in Estonia. The main tasks of the Board were declared to issue mandatory accounting guidelines and make recommendations concerning the methods which were to come into force. At that time the Board was independent governmental unit established by the government of Estonia and operating within the administrative jurisdiction of the Ministry of Finance. The Regulation was in force until 1995. This document introduced a number of new accounting concepts and principles, new terms and a new set of annual statements (included the balance sheet, the income statement and the statement of changes in the financial position and notes). The main characteristic of that period is that it was mixed from past (some elements of the former Soviet accounting system remained in force), present (real usage of new methods, principles and financial statements) and future (usage of many new terms of market economy which really were not represented in the Estonian economy). In accordance to the Regulation each enterprise was required to prepare a chart of accounts. In 1991 the accounting system was based on a chart of accounts published by the Ministry of Finance of the USSR. The former Soviet standard chart of accounts was officially used in Estonia until December 31, 1992. Since January 1, 1993 there is no standard chart of accounts in Estonia. Every company can introduce its own chart of accounts (Alver J., Alver L., 2008). Although, legally, the measure was a regulation and not statute (i.e. not approved by a legislative assembly but adopted by the executive action of the government) it was comparable to a fundamental, or basic, accounting law.

The second step started with the introduction of the first Estonian Accounting Act, which was passed by Parliament on June 8, 1994 and came into force on January 1, 1995. It was supported by introduction of the Estonian Commercial Code, which was passed by Parliament on February 15, 1995 and came into force on September 1, 1995. The Accounting Act did not contain a detailed set of rules and can best be characterized as constituting a legal framework. The legal framework was general and applied to all legal entities and physical persons registered as businesses in Estonia (referred to as accounting entities in the Act) with the exception of the Bank of Estonia (Alver et al., 2001). It was declared to be based on internationally recognized accounting principles, which were established with the Accounting Act and good accounting practice (Estonian accounting guidelines, Estonian GAAP). The true and fair view override was declared. The Accounting Act was supplemented by a number of methodological recommendations (guidelines) on accounting matters issued by the Estonian Accounting Board. These recommendations related to such accounting areas as accounting principles, preparation of financial statements, revenue recognition, business combinations and others. All together there were 16 accounting guidelines, which set up conceptual framework of generally accepted accounting principles, revenue recognition, business combination, leases, government grants, earning per share, long-term construction contracts. The only problem was that these guidelines were not for obligatory use. They were only recommendations and in the case of contradictions with the Accounting Act, requirements of the Accounting Act had to be followed. The first Accounting Act was in force until 2002 and was changed several times. Unfortunately, these changes were mostly cosmetic. No attempt was made to enlist the support of accounting community for changes in accounting practices. There was no publication of drafts of the Accounting Act prior to their enactment. There has been no general discussion of the purpose or the proper understanding of the required accounting changes or the manner of their implementation. 
Table 3. Main legal acts for regulation of accounting in the Republic of Estonia, 1990-2017

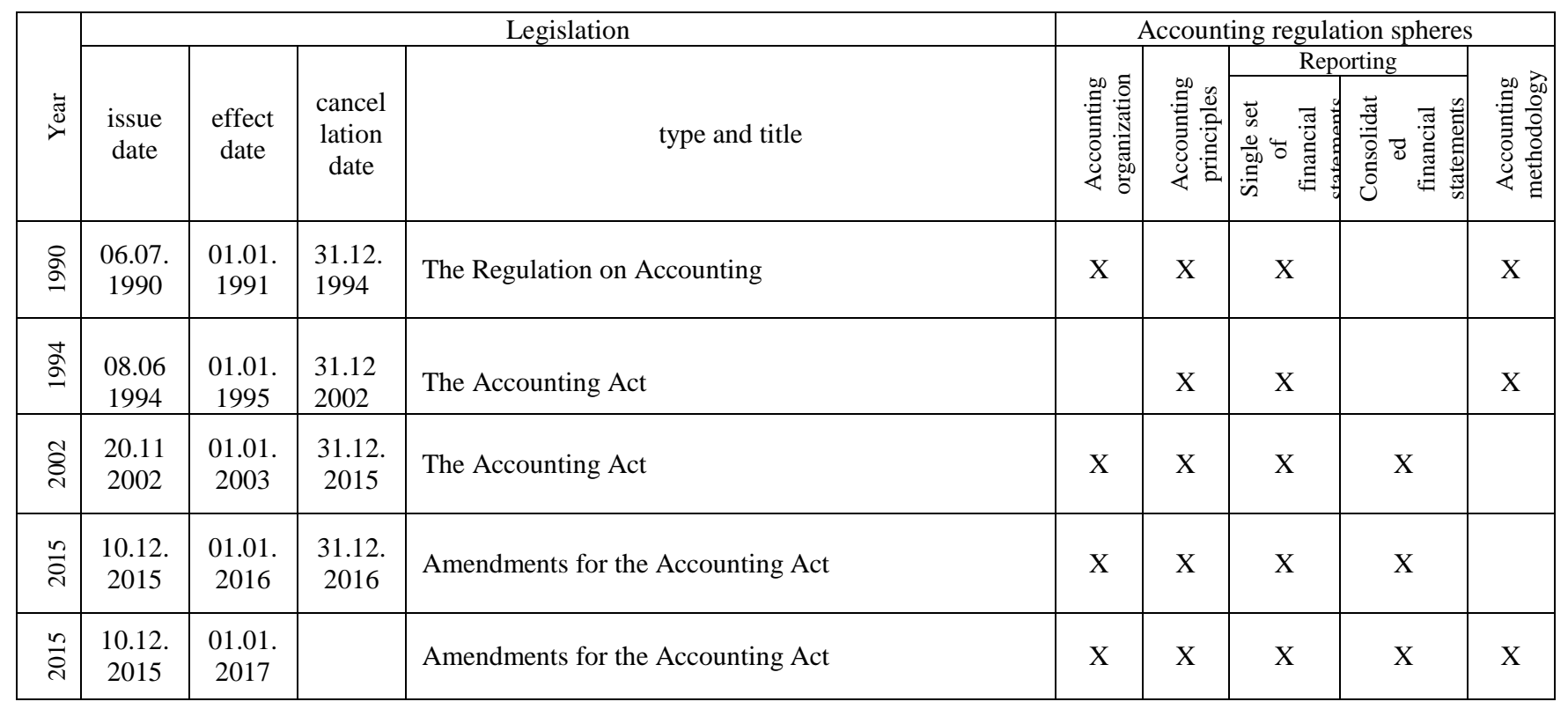

Source: Composed by authors according to references presented in the Table

The third step started with the introduction of the new Estonian Accounting Act, which was passed by Parliament on November 20, 2002 and came into force on January 1, 2003. The new Accounting Act modified the status of the Estonian Accounting Board, which became an independent commission. The Accounting Act regulated basic accounting functions in all business entities registered in Estonia. The Accounting Act included separate chapter for consolidated accounts and for organization of public accounting. In December of 2003, the Minister of Finance approved the General Rules for Public Sector Accounting which came into force on the 1st of January 2004. A major change was that the public sector accounting rules were brought in line with the basic accounting principles of the IPSAS (International Public Sector Accounting Standards). The essence of the law is framed in compliance with IFRSs. The accounting policies and presentation formats used in accounting shall be in line with the requirements and basic principles provided for in this Act and with at least one of the following two accounting frameworks: Estonian GAAP and IFRSs. For companies it is optional to select the Estonian GAAP or IFRSs for annual and consolidated accounts. It is the company's free choice to choose between IFRSs or Estonian Accounting Guidelines but if IFRSs selected than there is no need to prepare a second set of accounts in accordance with local accounting guidelines. Large companies are expected to choose the full IFRSs option (from 2005 the translated text of international standards is also available). Listed companies and financial institutions are required to prepare their accounts in accordance with IFRS. SMEs are likely to use the revised Estonian GAAP as their accounting framework.

In 2013 the Estonian Accounting Board decided to switch from the Full IFRS to the IFRS for SMEs. Rightness of this decision is supported by the data, which testify that only about $0.2 \%$ of all annual reports were prepared in accordance with IFRSs (MFRE, 2015). Until 2013 the Estonian GAAP was based on the Full IFRS and included 17 guidelines, which had in total of about 400 pages. As the volume of the guidelines was considerably lower than that of the Full IFRS, some accounting areas were covered only very briefly or not at all. In areas, which were not covered by the regulations the IFRS treatment was recommended, but was not mandatory. Each guideline included a brief comparison with the respective IFRS/IAS standards. Nevertheless, there were no conceptual 


\section{The International Journal}

ENTREPRENEURSHIP AND SUSTAINABILITY ISSUES

ISSN 2345-0282 (online) http://jssidoi.org/jesi/ 2018 Volume 6 Number 1 (September) http://doi.org/10.9770/jesi.2018.6.1(11)

differences between IFRSs and the guidelines. In some ways, the Estonian GAAP had less disclosure than IFRSs because it was allowed for SMEs. Therefore, large companies were expected to choose the Full IFRS option while other companies may use the set of the Estonian accounting guidelines as their accounting framework. Again, the guidelines had only status of recommendations. The main users of the Full IFRS are listed companies, banks, credit institutions, insurance companies, financial holding companies, mixed financial holding companies, investment firms and other large entities (Pacter, 2016). In Estonia about 99\% of companies are micro, small, or medium size entities and on that reason it has been too complicate to use the Full IFRS as a basis for the Estonian GAAP. The guidelines of the Estonian Accounting Board focus on the accounting areas that are relevant in Estonia. Because of this, despite the reliance of the IFRS for SMEs, the guidelines do not cover all areas that are regulated by the IFRS for SMEs, but only those, which are relevant for a large number of entities in Estonia. In those areas in which the guidelines do not specify a particular accounting policy but which are regulated by the IFRS for SMEs, it is recommended to use as the basis the accounting policy described in the IFRS for SMEs. The guidelines of contain references to the specific paragraphs of the IFRS for SMEs. For example, the reference to 13.4 of the IFRS for SMEs refers to paragraph 4 of section 13 "Inventories" of the IFRS for SMEs.

The last changes in accounting legislation took place in 2015 due to the fact that the Member States of the EU were required by 20 July 2015 to bring into force the laws, regulations and administrative provisions necessary to comply with the Accounting Directive 2013/34/EU. In 2015 the Accounting Act was amended to be in line with the new Accounting Directive. The main changes were related to the introduction of differentiation of entities and changes of the requirements of the content of annual reports depending on the size of companies. In accordance with the classification of entities large-sized and medium-sized entities must present four main statements (balance sheet, income statement, cash flow statement and statement of changes in owners' equity) and notes. The annual reports of small-sized and micro-sized entities following the Estonian GAAP comprise at least two main statements (balance sheet and income statement) and notes. Micro-sized entities are allowed to prepare the abridged annual reports where only classified balance sheet including subcategories of accounts (for example, current assets, long-term assets, current liabilities and etc.) must be presented. From 2017 the Estonian GAAP was renamed to the Estonian financial reporting standard.

\section{Evolution of accounting regulation in the Republic of Latvia}

Noticeable changes in Latvian accounting were possible after adopting the constitutional law of the Republic of Latvia "On the State Status of the Republic of Latvia" dated 21 August 1991, when Latvian economics started its movement again from planned economies to free market. After the laws "On Accounting" and "On the Annual Reports of Undertakings" came into force on 1 January 1993, a rearrangement of Latvian accounting system was started. Latvian accounting system was arranged in a similar way to the accounting system of Denmark. (Millere I., 2005)

When drafting those laws, the basic provisions of the EU Directives were applied. Accounting rules are outlined most profoundly in the Fourth Directive; therefore, the law "On Accounting" of the Republic of Latvia (LR) was based on that Directive. (Brūna I., Millere I., Šneidere R., 2006)

At present, Latvian accounting is regulated by one basic law, "On Accounting" adopted in 1992 with further amendments applied to all who carry on business, however, business activity according to "Commercial Law" is any systematic self-dependent activity paid for. According to paragraph 15 of the law "On Accounting", Regulation No.585 "Regulation Regarding the Conduct and Organisation of Accounting" was passed by the Cabinet of Ministers in 2003, and they apply to subjects of the law "On Accounting" and establish basic requirements for accounting arrangements and organisation. Nevertheless, it should be noted that this is the third version of the Regulations by the Cabinet of Ministers substituting the regulations adopted in 1995 and 2000, thus 
The International Journal

ENTREPRENEURSHIP AND SUSTAINABILITY ISSUES

ISSN 2345-0282 (online) http://jssidoi.org/jesi/

2018 Volume 6 Number 1 (September)

http://doi.org/10.9770/jesi.2018.6.1(11)

updating and clarifying the outdated requirements for organizing the accounting process as a whole as well as for specific issues, for example, composition of the document requisites when drafting electronic documents, etc. The law "On Accounting" also defines the criteria for keeping simple accounting records for farmers and fishermen farms, individual entrepreneurs, and individual contractors if the annual turnover does not exceed 300,000 EUR.

Except for those carrying on business activities and entitled to keep single entry accounting record system, all the others who have double entry accounting record system must submit annual reports according to the rules and requirements for filing provided in two fundamental laws "On the Annual Reports of Undertakings" and law "On the Consolidated Annual Reports" as well as other laws and legislative acts. The laws mentioned above do not apply to the members in financial and capital markets such as banks, insurance companies in the form of joint stock companies, private pension funds, etc. for whom the structure, scope, and content of annual reports as well as their preparation, auditing, and submitting procedure is regulated by laws for the activities of members in financial and capital markets such as "Law on Credit Unions", "Law on Financial Instrument Market", "Law on Insurance Agencies and Their Supervision" and other legislative acts adopted by the regulator, Financial and Capital Market Committee. The situation changed when pursuant to EU Directive 2013/34/EU of the European Parliament and of the Council of 26 June 2013 on the annual financial statements, consolidated financial statements and related reports of certain types of undertakings, a new law "On the Annual Financial Statements and Consolidated Financial Statements" was adopted in 2015 both by combining the two above mentioned laws and changing the existing rules for accounting record and content of financial statements significantly according to the requirements of the Directive.

Assessing the legal requirements of accounting record for the undertakers mentioned above of business activities, the conclusion is that laws and regulations contain the main accounting requirements and not detailed instructions for keeping accounting records. On the other hand, the elements for maintaining accounting records in state and local government agencies define the unified fundamental principle of bookkeeping and even the use of a chart of accounts in accounting. The requirements for maintaining accounting records in state and local government agencies are defined in the law "On Budget and Financial Management" adopted in 1994 and regulations on No.1486 "Procedure for Bookkeeping in Accounting Records in Budget Institutions" (15.12.2009). The preparation of annual reports in budget institutions is regulated by Regulations of the Cabinet of Ministers No.1115 "Procedure for Drafting Annual Report" (15.10.2013) which contain detailed procedure of preparing annual reports in public sector as well as the required forms and requirements for filling them up. The basic of the laws mentioned above regulating keeping accounting records and the applied accounting system in the Republic of Latvia have been summarised in Table 4.

Since legislative, regulatory acts in accounting do not give detailed solutions for many bookkeeping and evaluation issues just at the outset of accounting reforms there appeared a question about the application of International Accounting Standards (IAS) or working out Latvian Accounting Standards (LAS) as well as determining the subjects to whom their use is compulsory. The first attempt to work out and implement accounting standards failed. The law adopted on May 15, 2003 "On Accounting" had amendments stipulating the establishment of Accounting Council with the purpose to improve the quality of financial statements and compliance of legislative standards and regulations defining preparation of financial statements, with international accounting standards. (Millere I., 2005.)

Latvia made a decision to work out its own national accounting standards based on the traditional international accounting standards. Overall 11 Latvian accounting standards (LAS) have been adopted whose compulsory application was stipulated by Cabinet Regulation No. 201 "Regulations on Obligatory Applicable Latvian Accounting Standards" (27.03.2007) followed by amendments. Latvian accounting standards covered the most critical accounting areas: LAS 1 Guidelines for Drafting Financial Statement; LAS 2 Cash Flow Report; LAS 3 
The International Journal

ENTREPRENEURSHIP AND SUSTAINABILITY ISSUES

ISSN 2345-0282 (online) http://jssidoi.org/jesi/

2018 Volume 6 Number 1 (September)

http://doi.org/10.9770/jesi.2018.6.1(11)

Post Balance Sheet Events; LAS 4 Changes in Accounting Policy, Changes in Accounting Estimates and Historical Errors; LAS 5 Long-term Contracts; LAS 6 Revenue; LAS 7 Property, Plant and Equipment; LAS 8 Accruals, Contingent Liabilities and Contingent Assets; LAS 9 Investment Property; LAS 10 Lease; and LAS 11 Stocks. There was no essential difference between Latvian accounting standards concepts and International accounting standards (IAS).

Such a procedure was maintained in Latvia until 2011 when the Cabinet of Ministers ruled out the mandatory use of standards in accounting records of undertakings. Instead of the latter, the Cabinet of Ministers drafted and adopted Regulations No. 481 "Regulations on the Content and Procedure for Preparing the Cash Flow Report and Statement of Changes in Equity" and Cabinet Regulation No. 488 "Rules on the Application of the Law on Annual Accounts". There was an attempt to integrate the main rules from all pre-existing 11 accounting standards of Latvia, but their content was much more concentrated and created more problems for applying the requirements in practice. This Cabinet Regulation was in force until 2016, when Cabinet Regulation No. 775 "Regulations on the Application of the Law on Annual Accounts and Consolidated Annual Accounts" was approved two months after adopting the law "On Annual Report and Consolidated Annual Report" (22.12.2015), which together with the new Law were applicable to annual report for 2016. The most significant changes in the reduction of administrative burden by the Directive were the division of enterprises and groups from companies into four categories by setting composition and content of its annual report to each class and conditions for auditing. The changes also affected the presentation and assessment of several balance sheet items. The new order was assessed ambiguously as the amount of information to be included in the financial statements of micro and small companies was significantly reduced, although they account for $99 \%$ of the total number of enterprises in Latvia.

If the administrative burden is diminished, it influences the business environment positively, but on the other hand, there an unfavourable situation for the decision-makers about the volume, content, detailed level, and quality of available information might occur. If there would be only the minimum of the requirements set in Directive 2013/34/EU integrated into the national laws and rules for the regulation of accounting, the aboveindicated consequences might be observed not only in Latvia but also in the EU Member States with a small economy. (Brūna, Millere, 2015)

Table 4. Main legal acts for regulation of accounting in the Republic of Latvia, 1992-2017

\begin{tabular}{|c|c|c|c|c|c|c|c|c|c|c|}
\hline \multirow[b]{3}{*}{$\stackrel{\bar{d}}{\grave{D}}$} & \multirow[b]{3}{*}{$\begin{array}{l}\text { issue } \\
\text { date }\end{array}$} & \multirow[b]{3}{*}{$\begin{array}{c}\text { effect } \\
\text { date }\end{array}$} & \multicolumn{2}{|r|}{ Legislation } & \multicolumn{6}{|c|}{ Accounting regulation spheres } \\
\hline & & & & \multirow[b]{2}{*}{ type and title } & \multirow[b]{2}{*}{ 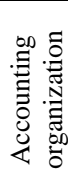 } & \multirow[b]{2}{*}{ 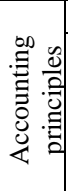 } & \multicolumn{3}{|c|}{ Reporting } & \multirow[b]{2}{*}{ 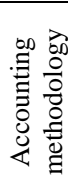 } \\
\hline & & & $\begin{array}{l}\text { cancel } \\
\text { lation } \\
\text { date }\end{array}$ & & & & 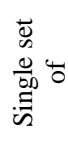 & 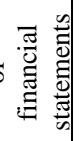 & 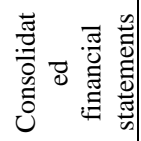 & \\
\hline 亏ू & $\begin{array}{c}12.11 . \\
1992\end{array}$ & $\begin{array}{c}01.01 . \\
1993\end{array}$ & & The Law On Accounting & $X$ & $\mathrm{X}$ & $X$ & & & $X$ \\
\hline ๙ू & $\begin{array}{c}12.11 . \\
1992\end{array}$ & $\begin{array}{c}01.01 . \\
1993\end{array}$ & $\begin{array}{l}01.01 \\
2016\end{array}$ & The Law On Annual Reports of Undertakings & & $\mathrm{X}$ & $\mathrm{X}$ & & $\mathrm{X}$ & $\mathrm{X}$ \\
\hline 2 ఫ & $\begin{array}{c}24.03 . \\
1994\end{array}$ & $\begin{array}{c}26.04 . \\
1994\end{array}$ & & The Law On Budget and Financial Management & $X$ & $\mathrm{X}$ & $\mathrm{X}$ & & & $\mathrm{X}$ \\
\hline$\stackrel{n}{\varrho}$ & $\begin{array}{c}07.11 . \\
1995\end{array}$ & $\begin{array}{c}18.11 . \\
1995\end{array}$ & $\begin{array}{c}01.10 \text {. } \\
2000\end{array}$ & $\begin{array}{l}\text { Regulations of the Cabinet of Ministers of Latvia No } \\
339 \\
\text { Regulation Regarding the Conduct and Organisation of } \\
\text { Accounting of Enterprises }\end{array}$ & $\mathrm{X}$ & $X$ & & & & \\
\hline
\end{tabular}


The International Journal

ENTREPRENEURSHIP AND SUSTAINABILITY ISSUES

ISSN 2345-0282 (online) http://jssidoi.org/jesi/

2018 Volume 6 Number 1 (September)

http://doi.org/10.9770/jesi.2018.6.1(11)

\begin{tabular}{|c|c|c|c|c|c|c|c|c|c|}
\hline \multirow[b]{3}{*}{ 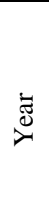 } & \multirow[b]{3}{*}{$\begin{array}{l}\text { issue } \\
\text { date }\end{array}$} & \multirow[b]{3}{*}{$\begin{array}{l}\text { effect } \\
\text { date }\end{array}$} & \multicolumn{2}{|r|}{ Legislation } & \multicolumn{5}{|c|}{ Accounting regulation spheres } \\
\hline & & & & \multirow[b]{2}{*}{ type and title } & \multirow[b]{2}{*}{ 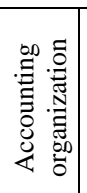 } & \multirow[b]{2}{*}{ 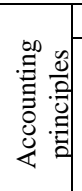 } & \multicolumn{2}{|c|}{ Reporting } & \multirow[b]{2}{*}{ 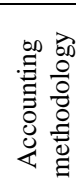 } \\
\hline & & & $\begin{array}{l}\text { cancel } \\
\text { lation } \\
\text { date }\end{array}$ & & & & 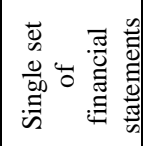 & 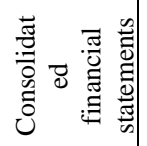 & \\
\hline ळे & $\begin{array}{c}30.09 . \\
1999\end{array}$ & $\begin{array}{c}01.01 . \\
2000\end{array}$ & $\begin{array}{c}22.11 \\
2006\end{array}$ & The Law On Consolidated Annual Accounts & & & & $\mathrm{X}$ & $\mathrm{X}$ \\
\hline ڤి & $\begin{array}{c}21.10 . \\
2003\end{array}$ & $\begin{array}{c}30.10 \\
2003\end{array}$ & & $\begin{array}{l}\text { Regulation of the Cabinet of Ministers of Latvia No } 585 \\
\text { Regulation Regarding the Conduct and Organisation of } \\
\text { Accounting }\end{array}$ & $\mathrm{X}$ & $\mathrm{X}$ & & & \\
\hline ஜे & $\begin{array}{c}18.10 . \\
2005\end{array}$ & $\begin{array}{c}22.10 \text {. } \\
2005\end{array}$ & $\begin{array}{c}31.03 . \\
2007\end{array}$ & $\begin{array}{l}\text { Regulation of the Cabinet of Ministers of Latvia No } 201 \\
\text { Regulations on Obligatory Applicable Latvian } \\
\text { Accounting Standards }\end{array}$ & & $\mathrm{X}$ & & & $X$ \\
\hline ఫ్ర & $\begin{array}{c}19.10 \\
2006\end{array}$ & $\begin{array}{c}22.11 \\
2006\end{array}$ & $\begin{array}{c}01.01 . \\
2016\end{array}$ & $\begin{array}{l}\text { New edition of The Law On Annual Reports of } \\
\text { Undertakings / new title-Annual Accounts Law } \\
\text { New edition of the Law On Consolidated Annual } \\
\text { Reports }\end{array}$ & & & $\mathrm{X}$ & $\mathrm{X}$ & $X$ \\
\hline $\overrightarrow{\check{c}}$ & $\begin{array}{c}21.06 . \\
2011\end{array}$ & $\begin{array}{c}01.07 . \\
2011\end{array}$ & $\begin{array}{c}01.01 . \\
2016\end{array}$ & $\begin{array}{l}\text { Regulation of the Cabinet of Ministers of Latvia No } 481 \\
\text { Regulations on the Content and Procedure for } \\
\text { Preparing the Cash Flow Report and Statement of } \\
\text { Changes in Equity }\end{array}$ & & & $\mathrm{X}$ & & $\mathrm{X}$ \\
\hline$\overline{\text { ন }}$ & $\begin{array}{c}21.06 . \\
2011\end{array}$ & $\begin{array}{c}01.07 . \\
2011\end{array}$ & $\begin{array}{c}01.01 . \\
2016\end{array}$ & $\begin{array}{l}\text { Regulations of the Cabinet of Ministers of Latvia No } \\
488 \\
\text { Rules on the Application of the Law on Annual Reports }\end{array}$ & & & $\mathrm{X}$ & $\mathrm{X}$ & $\mathrm{X}$ \\
\hline$\stackrel{m}{\stackrel{2}{2}}$ & $\begin{array}{c}15.10 . \\
2013\end{array}$ & $\begin{array}{c}01.11 . \\
2013\end{array}$ & & $\begin{array}{l}\text { Regulations of the Cabinet of Ministers of Latvia No } \\
1115 \\
\text { Procedure for Drafting Annual Report }\end{array}$ & & & $\mathrm{X}$ & & $X$ \\
\hline$\frac{n}{2}$ & $\begin{array}{c}22.10 . \\
2015\end{array}$ & $\begin{array}{c}01.01 \\
2016\end{array}$ & & $\begin{array}{l}\text { The Law on the Annual Financial Statements and } \\
\text { Consolidated Financial Statements }\end{array}$ & & $X$ & $\mathrm{X}$ & $\mathrm{X}$ & $\mathrm{X}$ \\
\hline$\frac{n}{2}$ & $\begin{array}{c}22.10 \\
2015\end{array}$ & $\begin{array}{c}01.01 . \\
2016\end{array}$ & & $\begin{array}{l}\text { Regulations of the Cabinet of Ministers of Latvia No } \\
775 \\
\text { Application Rules of the Law on the Annual Financial } \\
\text { Statements and Consolidated Financial Statements }\end{array}$ & & $X$ & $X$ & $X$ & $X$ \\
\hline
\end{tabular}

Source: Composed by authors according to references presented in the Table

In general, when analysing the development of Latvian accounting system at a time when it is significantly influenced by the processes of globalization, it should be concluded that after the restoration of Latvia's independence, it was repeatedly improved by adapting the legislation regulating accounting to the requirements of EU Directives and International Accounting Standards as much as possible. However, the nature of those changes indicates that until now, the Ministry of Finance of the Republic of Latvia does not follow a sound and sustainable accounting policy, although it is responsible for it. The fact that Latvia is both an EU Member State and a member of many other international organisations (International Monetary Fund, World Bank, World Trade Organization, OECD, etc.) has a positive impact on the development of accounting, as harmonization with the accounting systems of other countries is encouraged, but it also creates particular challenges such as selecting an appropriate accounting and valuation system, ensuring the quality of the annual reports and auditing, thus posing severe tasks for the future improvement of the Latvian accounting system. 
The International Journal

ENTREPRENEURSHIP AND SUSTAINABILITY ISSUES

ISSN 2345-0282 (online) http://jssidoi.org/jesi/

2018 Volume 6 Number 1 (September)

http://doi.org/10.9770/jesi.2018.6.1(11)

\section{Evolution of accounting regulation in the Republic of Lithuania}

Since 11 of March, 1990, when Lithuania regained its independence, the legal system of Lithuania has been reformed to meet the demands of the vast social and economic changes brought about by a return to democracy and a free market economic system. There has been a large scale of complicated changes faced by the national economy in the process of changeover from a state ownership to a private one. Many new private entities, especially medium and small-sized were established (Mackevičius, Zverovich, Kazlauskienė, 2011). Such situation required new legislation in all spheres as well as accounting. Although, till 1992, accounting used to be performed as a central planned economy accounting system based on detailed rules and instructions (Lakis, Subačienè, 2014), several important legislation on regulation of accounting were issued (see Table 5). The Resolution of the Government of the Republic of Lithuania „Due to the Taxation Rates of Amortization Deductions of Fixed Assets“ No. 368 (Lietuvos Respublikos, Vyriausybės nutarimas "Dèl pagrindinių..., 2017) was issued on 14 December, 1990 and was referred for all types and forms enterprises and organizations, irrespective of their ownership forms. The resolution stated, that all kinds of repairs had to be included into the sales' expenses of production (goods, works, services). It was also allowed to form a repair fund, if necessary. The resolution empowered Ministry of Economics, Ministry of Finance, Ministry of Industry and Department of Statistics to prepare and approve rules for the application of taxation rates of amortization deductions of fixed assets, which were widely used for calculation of depreciation and amortization not only for taxation purposes. Resolution of the Government of the Republic of Lithuania „Due to Organization of Accounting and Reporting“ No. 564 (Lietuvos Respublikos Vyriausybės nutarimas „Dèl buhalterinės..., 2017) was issued on 17 December, 1991. According to this resolution, companies had to organize accounting process in the way to provide timely and accurate information for state statistics, tax-calculating agencies, owners, creditors, business partners and to ensure legal framework for economic and commercial transactions (Lakis, Subačienè, 2014). The resolution enforced 5 international accounting standards for preparation of financial statements: IAS 1 Presentation of Financial Statements; IAS 2 Inventories; IAS 3 Consolidated Financial Statements (which was superseded in 1989 by IAS 27 and IAS 28), IAS 5 Information to Be Disclosed in Financial Statements, IAS 7 Statement of Cash Flows.

Although, during 1990 - 1992 period management of accounting methodology was appointed to the department of Accounting and reporting at the Department of Statistics and later for similar department at the Finance of Ministry of the Republic of Lithuania, but appointed functions were not implemented (Mackevičius, Subačienė, 2016a). So, during the accounting reformation from soviet accounting following the requirements of market economy many mistakes were made: no laws and other regulation documents on accounting were passed, an institution for accounting methodological management and supervision was not established, the concept for Lithuanian accounting restructuring and further development was not prepared, etc. (Mackevičius, Subačienė, 2016).

However, new level of accounting regulation started from 01 January, 1993, when the Law on the Principles of Accounting came into force (Lietuvos Respublikos Buhalterinès apskaitos pagrindų..., 2017). The Law obligated enterprises to organize their accounting procedures so that tax-accounting authorities, statisticians, creditors, and commercial partners could receive faithful and relevant information. It defined that accounting should be carried out in conformity with the provisions of International Accounting Standards and the European Union (formerly European Economic Community) Directives. This Law transferred accounting regulation from detail instructions to appliance of Generally Accepted Accounting Principles used in market economies, provided the procedure for the formalization and signing of documents confirming the execution of transactions, defined the composition and the procedure for the authorization of financial statements, the methods of assets valuation, stock-taking (Lakis, Subačienè, 2014). 


\section{The International Journal}

ENTREPRENEURSHIP AND SUSTAINABILITY ISSUES

ISSN 2345-0282 (online) http://jssidoi.org/jesi/ 2018 Volume 6 Number 1 (September) http://doi.org/10.9770/jesi.2018.6.1(11)

The Law on the Principles of Accounting was followed by several lower level legislation, which itemized some spheres of accounting. The Resolution of the Government of the Republic of Lithuania "Due to Annual Reporting of Legal Entities", No. 804 was issued 27 October, 1993 (Lietuvos Respublikos vyriausybès nutarimas "Dèl imonių..., 2017). The Resolution provided order for preparation of financial statements, their forms and structure, types of the sets of financial statements. Additionally, it defined order for recognition and accounting of revenue and expenditures. At the lowest level accounting was regulated by the letters of the Ministry of Finance of the Republic of Lithuania. For the period from 1993 to 2000 there were issued: letter "On the Typical Forms of Annual Reporting and Explanation of the Most Important Items", No. 83N, 12 November, 1993; letter "On the Explanatory Note and the Chart of Ledger Accounts", No. 91N, 16 December, 1993; letter "On Quarterly Reporting”, No. 24N, 22 March, 1994; letter "On Confirmation of Explanatory Note Forms”, No. 75, 23 May, 1997; letter "On Addition of Recommended Chart of Ledger Accounts", No. 88, 10 June, 1997; letter "On Financial Accounting Order for Grants and Subsidies", No. 65, 16 March, 1999; letter "On Financial Accounting Order for Leased Assets", No. 144, 5 June, 2000 and others, which were frequently amended. Although the Law on the Principles of Accounting started new phase of accounting regulation, but more significant practical importance has The Resolution of the Government of the Republic of Lithuania "Due to Annual Reporting of Legal Entities", No. 804 and other letters issued by the Ministry of Finance of the Republic of Lithuania (Mackevičius, 2005).

Important role in the process of development of accounting regulation had establishment of the Institute of Audit and Accounting by letter of the Ministry of Finance of the Republic of Lithuania "Due to Establishment of the Institute of Audit and Accounting", No. 71, 29 June, 1995. On 21 December 1998 the Institute was renamed to the Institute of Audit, Accounting and Property Valuation of the Republic of Lithuania and subsequently in 2002 - to the Institute of Accounting (Mackevičius, Zverovich, Kazlauskienè, 2011).

Yet the approval of the Law on the Principles of Accounting and related legislation was a substantial step toward the reorganization of accounting in Lithuania. However, regulation of accounting in Lithuania was incoherent and unsystematic, different spheres of accounting were regulated by various legislation of different significance: laws, resolutions, orders, letters (Subaciene, Macerinskiene, Budrionyte, 2012). Before 2001 Lithuanian enterprises had used tax laws for carrying out accounting process. However, some larger enterprises applied international accounting standards (Lakis, Subačienè, 2014).

New phase of accounting regulation development started in 2001, when three significant laws were issued: the Law on Accounting (Lietuvos Respublikos Buhalterinès apskaitos..., 2017), the Law on Financial Statements (Lietuvos Respublikos Imoniu finansinès atskaitomybès..., 2017), and the Law on Consolidated Financial Statements (Lietuvos Respublikos Imonių grupių..., 2017). The preparation process of the Law on Accounting lasted almost 3 years and has been started from 1998. During the process of preparation of the Law on Accounting, were prepared laws on Financial Statements and Consolidated Financial Statements (Mackevičius, 2005). Regardless of long laws' preparation process, it has to be highlighted, that these laws were complied with the Fourth (78/660/EEC) and Seventh (83/349/EEC) EU directives and started new phase of accounting regulation - integration to European accounting system (Бухгалтерский учет, 2007).

The Law on Accounting defines, that the general methodological management of accounting in accordance with the legislation of the Republic of Lithuania, in compliance with International Financial Reporting Standards and European Union law, is performed by the Ministry of Finance of the Republic of Lithuania. This Law regulates the arrangement of accounting. It also defines general requirements for the handling of accounting, the legalization and keeping of accounting documents and accounting registers, and the responsibility for the arrangement of accounting and safekeeping of documents. It specifies that legal entities have to apply provisions of the national accounting standards (Business Accounting Standards - in Lithuania), which regulate financial 
The International Journal

ENTREPRENEURSHIP AND SUSTAINABILITY ISSUES

ISSN 2345-0282 (online) http://jssidoi.org/jesi/

2018 Volume 6 Number 1 (September)

http://doi.org/10.9770/jesi.2018.6.1(11)

accounting of non-listed companies. Legal entities, whose securities are traded on a regulated market, have to apply international financial reporting standards (Lakis, Subačienè, 2014). The Law on Financial Statements (Lietuvos Respublikos Imoniu finansinès atskaitomybės..., 2017) defines the general accounting principles, the general requirements for the preparation of financial statements, financial period, confirmation and publishing of financial statements, the composition and description of financial statements, their types, the evaluation of assets and liabilities, responsibility for financial statements' preparation and keeping. It states, that financial statements are prepared in accordance with the general accounting principles and the Business Accounting Standards, too. The Law on Consolidated Financial Statements (Lietuvos Respublikos Imonių grupių..., 2017) specifies the terms and exceptions for the preparation of consolidated financial statements, composition and requirements for consolidated financial statements, requirements for consolidated financial statements' audit, confirmation and publishing. This law also refers, that consolidated financial statements are prepared according to the Law on Accounting, the Law on Financial Statements and Business Accounting Standards.

For regulation of different spheres and methodology of accounting were issued national accounting standards, which were called Business Accounting Standards. The adoption and revision of Business Accounting Standards was assigned to the Institute of Accounting (Lakis, Subačiené, 2014). On 18 December 2002, the Board of the Institute Of Accounting of the Republic of Lithuania approved first 17 Business Accounting Standards, which came into force from 01 January 2004 by the Law on Accounting. Since 2002 forty-two Business Accounting Standards have been developed. From September 2008 the Accounting Institute was renamed to the Audit and Accounting Authority (Mackevičius, Zverovich, Kazlauskienè, 2011) and from 2016 the Audit and Accounting Authority was reorganized into the Authority of Audit, Accounting, Property Valuation and Insolvency Management.

Directive 2013/34/EU of the European Parliament and of the Council of 26 June 2013 on the annual financial statements, consolidated financial statements and related reports of certain types of undertakings, amending Directive 2006/43/EC of the European Parliament and of the Council and repealing Council Directives 78/660/EEC and 83/349/EEC (Directive 2013/34/EU..., 2017) made a significant impact on changes of accounting regulation in Lithuania. The main aim of Directive to reduce the administrative burdens for micro enterprises, to prepare the framework for regulation of highest quality information, which should be prepared by enterprises. This Directive takes into account the Commission's better regulation programme, and, in particular, the Commission Communication entitled "Smart Regulation in the European Union", which aims at designing and delivering regulation of the highest quality whilst respecting the principles of subsidiarity and proportionality and ensuring that the administrative burdens are proportionate to the benefits they bring. The main provisions were transferred into Lithuanian legislation. The Law on Accounting, the Law on Financial Statements, the Law on Consolidated Financial Statements, Business Accounting Standards and other legislation were amended in 2015. Amendments came into effect since 2016 (Mackevičius, Subačienè, 2016). However, all types of legislation including laws (the Law on Accounting was amended 31 times; the Law on Financial Statements - 14 times; the Law on Consolidated Financial Statements - 12 times), resolutions, accounting standards (Business Accounting Standards were amended from 2 to 14 times) were amended since their issue, but amendments proceeded in 2015 were significant and made the biggest impact in arrangement of accounting for micro-enterprises. Moreover micro-enterprises makes around $80 \%$ of total number of enterprises in Lithuania (Mackevičius, Subačienė, 2016a). 2016 maybe distinguished as new evolution of accounting regulation phase.

Additionally has to be mentioned evolution of public sector accounting. Before 2005, public sectors subjects arranged accounting process under public delegated functions by modified monetary principle, monetary or accrual based principle. All transactions were recorded by received appropriations (inflows) and their usage (outflows). Under the Law on Accounting they had to apply standards for budget institutions, which were not issued yet. So, public sector subjects applied different types of legislation (Bikiene, 2011). 
The International Journal

ENTREPRENEURSHIP AND SUSTAINABILITY ISSUES

ISSN 2345-0282 (online) http://jssidoi.org/jesi/

2018 Volume 6 Number 1 (September)

http://doi.org/10.9770/jesi.2018.6.1(11)

Public sector accounting reform in Lithuania was conducted in accordance with the plan of modernization of financial management in the European Union and was initiated by the Resolution of the Government of the Republic of Lithuania "Due to the Conceptual Framework of the Public Sector Accounting and Financial Reporting System Reform and the Formation of a Commission for the Coordination and Monitoring of the Reform", which were issued on 29 June, 2005 (Lietuvos Respublikos Vyriausybès nutarimas "Dèl viešojo sektoriaus..., 2017). The first step in this direction was the application of accrual based accounting principle. According to the plan of the European Commission, in January 2005, a new accounting system came into effect and new rules for accounting, based on International Public Sector Accounting Standards (IPSAS) were set. (Lakis, Subačienè, 2014). On 26 June, 2007 the Law on Public Sector Financial Statements in the Republic of Lithuania was passed and came into force from 01 January 2008. The Law (Lietuvos Respublikos Viešojo..., 2017) defines generally accepted accounting principles, composition of public sector financial statements, general, official registration's and additional requirements for public sector financial statements, requirements for consolidated financial statements, evaluation of assets, funding and liabilities, responsibility for preparation, signing, publication and keeping of public sector financial statements. Until the end of 2008 twenty six Public Sector Accounting Standards, general chart of ledger accounts for public sector, manuals for different public sector institutions, consolidation manual, recommendations for different groups of public sector subjects were prepared and confirmed, amended related legislation (Mackevičius, Subačienè, 2016a). Since public sector accounting reform twenty-eight Public Sector Accounting Standards have been developed.

Table 5. Main legal acts for regulation of accounting in the Republic of Lithuania, 1990-2017

\begin{tabular}{|c|c|c|c|c|c|c|c|c|c|}
\hline \multirow[b]{3}{*}{$\stackrel{\vec{d}}{\grave{D}}$} & \multirow[b]{3}{*}{$\begin{array}{l}\text { issue } \\
\text { date }\end{array}$} & \multirow[b]{3}{*}{$\begin{array}{c}\text { effect } \\
\text { date }\end{array}$} & \multicolumn{2}{|r|}{ Legislation } & \multicolumn{5}{|c|}{ Accounting regulation spheres } \\
\hline & & & & \multirow[b]{2}{*}{ type and title } & \multirow[b]{2}{*}{ 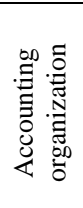 } & \multirow[b]{2}{*}{ 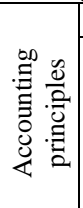 } & \multicolumn{2}{|c|}{ Reporting } & \multirow[b]{2}{*}{ 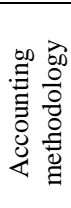 } \\
\hline & & & $\begin{array}{l}\text { cancel } \\
\text { ation } \\
\text { date }\end{array}$ & & & & 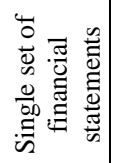 & 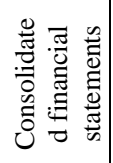 & \\
\hline よ & $\begin{array}{c}14.12 . \\
1990\end{array}$ & $\begin{array}{c}14.12 . \\
1990\end{array}$ & $\begin{array}{c}01.04 . \\
1994\end{array}$ & $\begin{array}{l}\text { Resolution of Government of Republic of Lithuania } \\
\text { „Due to the Taxation Rates of Amortization Deductions } \\
\text { of Fixed Assets“ No. } 368\end{array}$ & & & & & $X$ \\
\hline $\bar{\Omega}$ & $\begin{array}{c}17.12 . \\
1991\end{array}$ & $\begin{array}{c}17.12 \\
1991\end{array}$ & $\begin{array}{c}11.02 . \\
2005\end{array}$ & $\begin{array}{l}\text { Resolution of Government of Republic of Lithuania } \\
\text { „Due to Organization of Accounting and Reporting“ } \\
\text { No. } 564\end{array}$ & $\mathrm{X}$ & & $\mathrm{X}$ & $X$ & $X$ \\
\hline$\delta$ & $\begin{array}{c}18.06 . \\
1992\end{array}$ & $\begin{array}{c}01.01 . \\
1993\end{array}$ & $\begin{array}{c}01.01 . \\
2002\end{array}$ & The Law on the Principles of Accounting No. I-2654 & $X$ & $X$ & $\mathrm{X}$ & & $\mathrm{X}$ \\
\hline ๙ & $\begin{array}{c}27.10 . \\
1993\end{array}$ & $\begin{array}{c}01.01 . \\
1994\end{array}$ & $\begin{array}{c}11.02 . \\
2005\end{array}$ & $\begin{array}{l}\text { Resolution of the Government of the Republic of } \\
\text { Lithuania "Due to Annual Reporting of Legal Entities" } \\
\text { No. } 804\end{array}$ & & & $\mathrm{X}$ & & $X$ \\
\hline ठ্ণ & $\begin{array}{c}06.11 . \\
2001\end{array}$ & $\begin{array}{c}01.01 . \\
2002\end{array}$ & & The Law on Accounting No. IX-574 & $X$ & & & & $X$ \\
\hline ষ্ণ & $\begin{array}{c}06.11 . \\
2001\end{array}$ & $\begin{array}{c}01.01 . \\
2003\end{array}$ & & The Law on Financial Statements No. IX-575 & & $X$ & $\mathrm{X}$ & & \\
\hline ळ্ণ & $\begin{array}{c}06.11 . \\
2001\end{array}$ & $\begin{array}{c}01.01 . \\
2004\end{array}$ & & $\begin{array}{l}\text { The Law on Consolidated Financial Statements No. IX- } \\
576\end{array}$ & & & & $X$ & \\
\hline 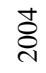 & $\begin{array}{l}\text { End of } \\
2003\end{array}$ & $\begin{array}{c}01.01 . \\
2004\end{array}$ & & Business Accounting Standards & & & & & $\mathrm{X}$ \\
\hline
\end{tabular}




\begin{tabular}{|c|c|c|c|c|c|c|c|c|c|}
\hline \multirow[b]{3}{*}{$\stackrel{\varpi}{\beth}$} & \multirow[b]{3}{*}{$\begin{array}{l}\text { issue } \\
\text { date }\end{array}$} & \multirow[b]{3}{*}{$\begin{array}{c}\text { effect } \\
\text { date }\end{array}$} & \multicolumn{2}{|r|}{ Legislation } & \multicolumn{5}{|c|}{ Accounting regulation spheres } \\
\hline & & & & & \multirow[b]{2}{*}{ 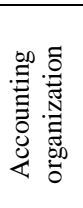 } & \multirow[b]{2}{*}{ 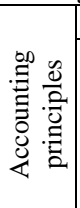 } & \multicolumn{2}{|c|}{ Reporting } & \multirow[b]{2}{*}{ 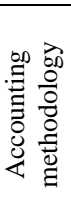 } \\
\hline & & & $\begin{array}{l}\text { cancel } \\
\text { ation } \\
\text { date }\end{array}$ & type and title & & & 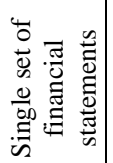 & 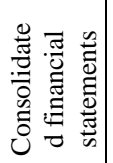 & \\
\hline$\overbrace{\tilde{c}}^{2}$ & $\begin{array}{c}29.06 . \\
2005\end{array}$ & $\begin{array}{l}01.07 . \\
2005\end{array}$ & & $\begin{array}{l}\text { Resolution of the Government of the Republic of } \\
\text { Lithuania "Due to the Conceptual Framework of the } \\
\text { Public Sector Accounting and Financial Reporting } \\
\text { System Reform and the Formation of a Commission for } \\
\text { the Coordination and Monitoring of the Reform" } \\
\text { No.718 }\end{array}$ & $\mathrm{X}$ & & & & \\
\hline$\hat{8}$ & $\begin{array}{c}26.06 . \\
2007\end{array}$ & $\begin{array}{c}01.01 . \\
2008\end{array}$ & & $\begin{array}{l}\text { The Law on Public Sector Financial Statements in the } \\
\text { Republic of Lithuania }\end{array}$ & & $\mathrm{X}$ & $\mathrm{X}$ & $\mathrm{X}$ & \\
\hline 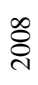 & $\begin{array}{l}2007- \\
2008\end{array}$ & $\begin{array}{c}01.01 \\
2008\end{array}$ & & Public Sector Accounting Standards & & & & & $\mathrm{X}$ \\
\hline$\stackrel{n}{\stackrel{2}{c}}$ & 2015 & $\begin{array}{c}01.01 \\
2016\end{array}$ & & Amendments for the Law on Accounting & $\mathrm{X}$ & & & & \\
\hline$\stackrel{n}{\stackrel{4}{2}}$ & $\begin{array}{l}14.05 . \\
2015\end{array}$ & $\begin{array}{l}01.01 . \\
2016\end{array}$ & & $\begin{array}{l}\text { New edition of The Law on Financial Statements No. } \\
\text { XII-1696 }\end{array}$ & & & $\mathrm{X}$ & & \\
\hline$\stackrel{n}{\frac{n}{2}}$ & $\begin{array}{l}14.05 . \\
2015\end{array}$ & $\begin{array}{c}01.01 \\
2016\end{array}$ & & $\begin{array}{l}\text { New edition of The Law on Consolidated Financial } \\
\text { Statements No. XII-1697 }\end{array}$ & & & & $\mathrm{X}$ & \\
\hline
\end{tabular}

Source: Composed by authors according to references presented in the Table

After the accounting reform in public sector, accounting in the Republic of Lithuania is regulated at the three levels. First level includes the Law on Accounting, second level is based on laws which regulate requirements for the information provided in the financial statements and preparation of financial statements (the Law on Financial Statements and the Law on Consolidated Financial Statements for private sector; the Law on Public Sector Financial Statements for public sector), the third accounting regulation level includes Business Accounting Standards or International Financial Reporting Standards for private sector and Public Sector Accounting and Financial Reporting Standards, accordingly (Lakis, Subačienė, 2014).

\section{Evolution of accounting regulation in the Slovak Republic}

In March 29, 1990 the Czechoslovak Socialistic Republic renamed to the Czech-Slovak Federative Republic (since April 23, 1990 - Czech and Slovak Federative Republic) with Slovakia as a part of it. Slovakia had the same cultural, political, legislative and social background as the Czech Republic until the end of 1992. The changes in these areas were first connected with the Velvet Revolution in 1989 and then following with the peaceful partition of the Czech and Slovak Federative Republic (CSFR) in 1993. The development in accounting legislation had assimilated to the changed conditions in the political and economic situation. Until December 1991 the integrated system of social-economic information was implemented and applied as in the central planned economy. The period between 1989 and 1991 was a kind of transitional period of gradual and progressive change in accounting system. In this period new legislation was issued with the force from January 1, 1990 and effectiveness only until December 31, 1991. There were issued: the Act No. 128/1989 Coll. which amended the 
The International Journal

ENTREPRENEURSHIP AND SUSTAINABILITY ISSUES

ISSN 2345-0282 (online) http://jssidoi.org/jesi/

2018 Volume 6 Number 1 (September)

http://doi.org/10.9770/jesi.2018.6.1(11)

most important act in the central planned economy - Act No. 21/1971 Coll. on integrated system of socialeconomic information; the regulation of CSFR's government No. 136/1989 on information system of organisations and several ordinances connected with charts of accounts and accounting (Šlosár, 2008) and later on Federal Ministry of Finance adopted Decree No. 23/1990 Coll., on Accounting, that came to force on 1 March 1990.

The transformation from the central planned economy to free market economy system with the private not only state ownership and need of national and international accounting information comparison requested radical reform of accounting system. One of the initial stages of this reform was the enactment of the obligation for accounting entities to maintain their accounts in the Commercial Code No. 513/1991 of 5 November 1991 and effective since January 1, 1992. The result of this reform was the first act on accounting in modern history - Act No. 563/1991 Coll. on Accounting approved by the CSFR's federal assembly on December 12, 1991 and effective from January 1, 1992. This act introduced more comprehensive accounting information system with a new methodology in the system on the basis of cash receipts and disbursements and in the system of double entry bookkeeping and it also introduced for the first time rules for the consolidated financial statements. In accord with the Act No. 563/1991 Coll. on Accounting several decrees were issued and applied by the Federal Ministry of Finance e.g. Decree No. V/20100/1992 of 15 July 1992 laying down the framework for the chart of accounts and details of the accounting procedures for entrepreneurs (see Table 6). Other types of accounting entities (e.g. banks, insurance companies) were regulated by separate decrees laying down their frameworks for the chart of accounts, details of the accounting procedures and financial statements.

The Slovak Republic has achieved its independence since January 1, 1993. The Commercial Code No. 513/1991, Act No. 563/1991 Coll. on Accounting, Decree No. V/20100/1992 of 15 July 1992 laying down the framework for the chart of accounts and details of the accounting procedures for entrepreneurs, sole traders and decrees for other types of accounting entities (e.g. municipalities, non-profit organizations, political parties, civic associations, banks, health insurance companies, insurance companies) have been kept and later several times amended by the Ministry of Finance of the Slovak Republic. Except for decrees for accounting procedures there were also single decrees for financial statements for entrepreneurs (Table 6) and for other types of accounting entities. The rules for consolidated financial statements were provided undetailed in two paragraphs ( $\$ 22$ and 23) of the Act No. 563/1991 Coll. on Accounting as amended. That is why the Ministry of Finance of the Slovak Republic issued Decree No. 65/393/1993 of 22 December 1993 on the preparation of the consolidated financial statements. The Slovak Republic had had an intention to become part of the European integration since its early establishment that is why the Ministry of Finance incorporated the rules of the Seventh EU directive (83/349/EEC) and International Accounting Standards. First consolidated financial statements ever were prepared as of 31 December 1993 in accordance with the topical accounting legislation valid in the Slovak Republic at that time. In 1994 the Ministry of Finance of the Slovak Republic issued two analogical degrees (Table 6) on the preparation of the consolidated financial statements of banks and consolidated financial statements of insurance companies (Farkaš, 2013).

A significant change came with the access negotiations of the Slovak Republic to the European Union. The Slovak legislation needed to be fully harmonized with the regulations of the European Union before its official membership since May 1, 2004. The Ministry of Finance of the Slovak Republic had developed and issued a new act on accounting, Act No. 431/2002 Coll. on Accounting which came into force on January 1, 2003 (there was an exception for "financial year", this paragraph came into force one year later). The Act No. 431/2002 Coll. on Accounting as amended (hereafter: Act on Accounting) has the primacy in the Slovak accounting legislation and cancelled the previous Act No. 563/1991 Coll. on Accounting including all decrees which were published in accordance with the previous act. It is a general act for all types of accounting entities without setting specifics for individual types of accounting entities (Šlosár, 2008). The obligation for entrepreneurs to maintain their accounts 
The International Journal

ENTREPRENEURSHIP AND SUSTAINABILITY ISSUES

ISSN 2345-0282 (online) http://jssidoi.org/jesi/ 2018 Volume 6 Number 1 (September) http://doi.org/10.9770/jesi.2018.6.1(11)

is stated in the Commercial Code No. 513/1991 as amended (Chapter IV, Articles 35-40). This obligation is connected with the fact that every type of business uses accounting and the types of business, including their features, are also defined in the Commercial Code. (Hladika, Mokošová, Molín, 2017). The new Act on Accounting was complied with the Fourth EU directive (78/660/EEC), the Seventh EU directive (83/349/EEC), the Eight EU directive (84/253/EEC), other EU directives which set additional requirements in specific issues (e.g. individual and consolidated financial statements of banks or insurance companies) and with the some definitions and concepts of International Accounting Standards. In connection with the new Act on Accounting several decrees were issued. They contained the rules for maintaining accounts in double entry bookkeeping by different types of accounting entities, frameworks chart of accounts and financial statements and one degree for the basis of cash receipts and disbursements. Since 2003 were in force: Decree of the Ministry of Finance of the Slovak Republic No. 23 054/2002-92 of 16 December 2002, laying down details of the accounting procedures and the framework for the chart of accounts for entrepreneurs maintaining accounts under the system of double entry bookkeeping (hereafter: Decree of the MFSR on double entry bookkeeping for entrepreneurs); Decree of the Ministry of Finance of the Slovak Republic No. 4455/2003-92 of 31 March 2003, laying down details of the structure, description and content of items of financial statements for an individual entity and the extent of data contained in these financial statements to be published by entrepreneurs maintaining accounts under the system of double entry bookkeeping; Decree of the Ministry of Finance of the Slovak Republic No. 23586/2002-92 of 17 December 2002, laying down details of the accounting procedures and details of the structure, description and content of items of financial statements and the extent of data contained in these financial statements to be published by entrepreneurs maintaining accounts under the basis of cash receipts and disbursements, doing business or undertaking other independent earning activities where they report expenses incurred for acquiring, assuring and maintaining income in order to determine their income tax (hereafter: Decree of the MFSR on single entry bookkeeping for entrepreneurs). In 2002 - 2003 new decrees on accounting procedures, framework for the chart of accounts and financial statements for other types of accounting entities (e.g. the Slovak National Bank, health insurance companies, state funds) were issued by the Ministry of Finance of the Slovak Republic.

In connection with the new Act on Accounting next three decrees on the preparation of consolidated financial statements (separately for entrepreneurs, banks and insurance companies) were issued by the Ministry of Finance of the Slovak Republic. These three decrees had been effective only for two years 2003-2004, because the Slovak Republic implemented Regulation (EC) No. 1606/2002 of the European Parliament and of the Council of 19 July 2002 on the application of international accounting standards and in this respect amended the Act on Accounting (Parišová, 2010). This amendment caused the repeal not only above mentioned three decrees on consolidated financial statements, but also decrees on maintaining accounts and framework charts of accounts for banks, insurance companies and large companies. The Slovak Republic had enforced the Article 4 and 5 of Regulation (EC) No. 1606/2002 and applied the IFRS as adopted by the EU for preparation of all consolidated financial statements (with the exception of consolidated financial statements of public administration accounting entities) since 2005 and individual financial statements of banks, insurance companies and large companies since 2006. The obligation to prepare the consolidated financial statements remains in the amended Act on Accounting and if accounting entities meets the requirements, then they have to prepare the consolidated financial statements in accordance with IFRS as adopted by the EU (Farkaš, 2013).

The guiding principle "think small first" implemented by the European Commission in its last accounting directive (Directive 2013/34/EU of the European Parliament and of the Council of 26 June 2013 on the annual financial statements, consolidated financial statements and related reports of certain types of undertakings as amended) in order to further simplify the requirements for SMEs has significantly impacted the Slovak accounting regulation. First of all the Act on Accounting was amended and the size criteria for classification of entrepreneurs were harmonized with the Directive 2013/34/EU. Accounting entities are classified into micro, small, large accounting entities and public interest entities in accordance with the Act on Accounting (Article 2 
The International Journal

ENTREPRENEURSHIP AND SUSTAINABILITY ISSUES

ISSN 2345-0282 (online) http://jssidoi.org/jesi/ 2018 Volume 6 Number 1 (September) http://doi.org/10.9770/jesi.2018.6.1(11)

(5) to (12)) which amendment came into force on January 1, 2015. This amendment of Act on Accounting caused the repeal of the Decree of the Ministry of Finance of the Slovak Republic No. 4455/2003-92 laying down details of the structure, description and content of items of financial statements for an individual entity and the extent of data contained in these financial statements to be published by entrepreneurs maintaining accounts under the system of double entry bookkeeping and the implementation of two new decrees: Decree of the Ministry of Finance of the Slovak Republic No. MF/23377/2014-74 of 3 December 2014 laying down details of the structure, description and content of items of individual financial statements for large accounting entities and public interest entities, as amended and Decree of the Ministry of Finance of the Slovak Republic No. MF/23378/2014-74 of 3 December 2014 laying down details of the structure, description and content of items of individual financial statements for small accounting entities, as amended with the effectiveness of amendments on January 1, 2016. Both of these new decrees have been amended once since their force on January 1, 2015. The decree for micro accounting entities was issued one year earlier as Decree of the Ministry of Finance of the Slovak Republic No. MF/15464/2013-74 of 11 December 2013 laying down details of the structure, description and content of items of individual financial statements for micro accounting entities, as amended (amended once since January 1, 2014). The amendments of Act on Accounting, Decree of the MFSR on double entry bookkeeping for entrepreneurs and new decrees for financial statements applied certain simplifications of accounting procedures and preparation of financial statements for micro and small accounting entities.

Topical version of the Act on Accounting consists of nine parts and except for the accounting systems it also defines other principal accounting issues such as accounting documents, accounting entries, accounting books, framework for the chart of accounts and accounting entity's chart of accounts, financial statements, audit of financial statements by an auditor, annual report, consolidated financial statements, register, valuation methods, reconciliation procedures, accounting documentation (Hladika, Mokošová, Molín, 2017). Since 2002 the Act on Accounting has been amended 25 times and Decree of the MFSR on double entry bookkeeping for entrepreneurs has been amended 14 times. Decree of the MFSR on single entry bookkeeping for entrepreneurs (new decree from 2007) has been amended 8 times.

Table 6. Main legal accounting regulation for entrepreneurs in the Slovak Republic, 1993-2017

\begin{tabular}{|c|c|c|c|c|c|c|c|c|c|}
\hline \multirow[b]{3}{*}{ 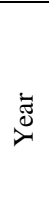 } & \multicolumn{4}{|r|}{ Legislation } & \multicolumn{5}{|c|}{ Accounting regulation spheres } \\
\hline & \multirow[b]{2}{*}{$\begin{array}{l}\text { issue } \\
\text { date }\end{array}$} & \multirow[b]{2}{*}{$\begin{array}{l}\text { effect } \\
\text { date }\end{array}$} & \multirow[b]{2}{*}{$\begin{array}{l}\text { cancel } \\
\text { ation } \\
\text { date }\end{array}$} & \multirow[b]{2}{*}{ type and title } & \multirow[b]{2}{*}{ 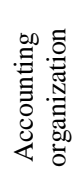 } & \multirow[b]{2}{*}{ 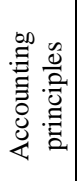 } & \multicolumn{2}{|c|}{ Reporting } & \multirow[b]{2}{*}{ 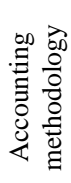 } \\
\hline & & & & & & & 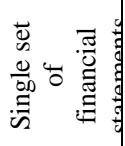 & 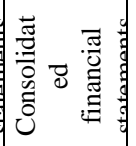 & \\
\hline$\Xi$ & $\begin{array}{c}12.12 . \\
1991\end{array}$ & $\begin{array}{c}01.01 . \\
1992\end{array}$ & $\begin{array}{c}31.12 . \\
2002\end{array}$ & Act No. 563/1991 Coll. on Accounting & $X$ & $X$ & $\mathrm{X}$ & $\mathrm{X}$ & $\mathrm{X}$ \\
\hline & $\begin{array}{c}15.07 \\
1992\end{array}$ & $\begin{array}{c}01.01 . \\
1993\end{array}$ & $\begin{array}{c}31.12 . \\
1998\end{array}$ & $\begin{array}{l}\text { Decree No. V/20100/1992 of } 15 \text { July } 1992 \text { laying down the } \\
\text { framework for the chart of accounts and details of the } \\
\text { accounting procedures for entrepreneurs }\end{array}$ & & & & & $X$ \\
\hline & $\begin{array}{c}23.12 . \\
1992\end{array}$ & $\begin{array}{c}01.01 . \\
1993\end{array}$ & $\begin{array}{c}07.09 . \\
1994\end{array}$ & $\begin{array}{l}\text { Decree No. V/1-31 370/1992 of } 23 \text { December } 1992 \text { laying } \\
\text { down details of the accounting procedures for sole traders } \\
\text { carrying out business activities or other activities generating } \\
\text { income under the basis of cash receipts and disbursements }\end{array}$ & & & $X$ & & $X$ \\
\hline 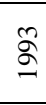 & $\begin{array}{c}29.12 . \\
1992\end{array}$ & $\begin{array}{c}01.01 . \\
1993\end{array}$ & $\begin{array}{c}09.04 \\
2003\end{array}$ & $\begin{array}{l}\text { Decree No. V/1- } 31388 / 1992 \text { of } 29 \text { December } 1992 \text { laying } \\
\text { down the structure and content of items of the balance sheet } \\
\text { and the income statement for entrepreneurs }\end{array}$ & & & $X$ & & $X$ \\
\hline 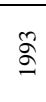 & $\begin{array}{c}15.11 . \\
1993\end{array}$ & $\begin{array}{c}30.11 . \\
1993\end{array}$ & $\begin{array}{l}09.04 . \\
2003\end{array}$ & $\begin{array}{l}\text { Decree No. } 65 / 277 / 1993 \text { of } 15 \text { November } 1993 \text { laying down } \\
\text { the content of the notes forming part of financial statements of } \\
\text { entrepreneurs }\end{array}$ & & & $\mathrm{X}$ & & $\mathrm{X}$ \\
\hline
\end{tabular}


The International Journal

ENTREPRENEURSHIP AND SUSTAINABILITY ISSUES

ISSN 2345-0282 (online) http://jssidoi.org/jesi/

2018 Volume 6 Number 1 (September)

http://doi.org/10.9770/jesi.2018.6.1(11)

\begin{tabular}{|c|c|c|c|c|c|c|c|c|c|}
\hline \multirow[b]{3}{*}{$\stackrel{\varpi}{\circlearrowright}$} & \multicolumn{4}{|r|}{ Legislation } & \multicolumn{5}{|c|}{ Accounting regulation spheres } \\
\hline & \multirow[b]{2}{*}{$\begin{array}{l}\text { issue } \\
\text { date }\end{array}$} & \multirow[b]{2}{*}{$\begin{array}{l}\text { effect } \\
\text { date }\end{array}$} & \multirow[b]{2}{*}{$\begin{array}{l}\text { cancel } \\
\text { ation } \\
\text { date }\end{array}$} & \multirow[b]{2}{*}{ type and title } & \multirow[b]{2}{*}{ 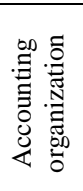 } & \multirow[b]{2}{*}{ 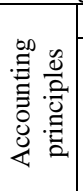 } & \multicolumn{2}{|c|}{ Reporting } & \multirow[b]{2}{*}{ 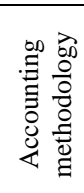 } \\
\hline & & & & & & & 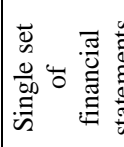 & 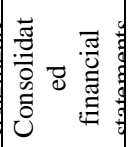 & \\
\hline$\hat{\Omega}$ & $\begin{array}{c}22.12 . \\
1993\end{array}$ & $\begin{array}{c}25.01 . \\
1994\end{array}$ & $\begin{array}{c}30.11 . \\
2003\end{array}$ & $\begin{array}{l}\text { Decree No. } 65 / 393 / 1993 \text { of } 22 \text { December } 1993 \text { on the } \\
\text { preparation of the consolidated financial statements }\end{array}$ & & & & $\mathrm{X}$ & $\mathrm{X}$ \\
\hline よે & $\begin{array}{c}19.08 . \\
1994\end{array}$ & $\begin{array}{c}08.09 \\
1994\end{array}$ & $\begin{array}{l}31.12 . \\
2008\end{array}$ & $\begin{array}{l}\text { Decree No. 65/396/1994 of } 19 \text { August } 1994 \text { laying down } \\
\text { details of the accounting procedures for sole traders } \\
\text { maintaining accounts under the basis of cash receipts and } \\
\text { disbursements, doing business or undertaking other } \\
\text { independent earning activities where they report expenses } \\
\text { incurred for acquiring, assuring and maintaining income in } \\
\text { order to determine their income tax }\end{array}$ & & & $\mathrm{X}$ & & $\mathrm{X}$ \\
\hline Дे & $\begin{array}{c}23.05 . \\
1994\end{array}$ & $\begin{array}{c}18.08 . \\
1994\end{array}$ & $\begin{array}{l}31.07 . \\
2003\end{array}$ & $\begin{array}{l}\text { Decree No. } 65 / 253 / 1994 \text { of } 23 \text { May } 1994 \text { on the preparation of } \\
\text { the consolidated financial statements of insurance companies }\end{array}$ & & & & $\mathrm{X}$ & $\mathrm{X}$ \\
\hline ‡े & $\begin{array}{c}23.05 . \\
1994\end{array}$ & $\begin{array}{c}18.08 . \\
1994\end{array}$ & $\begin{array}{c}31.05 . \\
2003\end{array}$ & $\begin{array}{l}\text { Decree No. } 65 / 252 / 1994 \text { of } 23 \text { May } 1994 \text { on the preparation of } \\
\text { the consolidated financial statements of banks }\end{array}$ & & & & $\mathrm{X}$ & $\mathrm{X}$ \\
\hline$\stackrel{2}{\curvearrowright}$ & $\begin{array}{c}16.11 . \\
1998\end{array}$ & $\begin{array}{c}01.01 . \\
1999\end{array}$ & $\begin{array}{l}31.12 . \\
2002\end{array}$ & $\begin{array}{l}\text { Decree No. } 3177 / 1998-\mathrm{KM} \text { of } 16 \text { November } 1998 \text { regulating } \\
\text { the chart of accounts and accounting procedures for } \\
\text { entrepreneurs }\end{array}$ & & & & & $\mathrm{X}$ \\
\hline §̊ & $\begin{array}{c}18.06 . \\
2002\end{array}$ & $\begin{array}{c}01.01 . \\
2003\end{array}$ & & Act No. 431/2002 Coll. on Accounting & $\mathrm{X}$ & $\mathrm{X}$ & $\mathrm{X}$ & $\mathrm{X}$ & $\mathrm{X}$ \\
\hline ઠิ & $\begin{array}{l}16.12 . \\
2002\end{array}$ & $\begin{array}{l}01.01 . \\
2003\end{array}$ & & $\begin{array}{l}\text { Decree No. } 23054 / 2002-92 \text { of } 16 \text { December } 2002 \text {, laying } \\
\text { down details of the accounting procedures and the framework } \\
\text { for the chart of accounts for entrepreneurs maintaining } \\
\text { accounts under the system of double entry bookkeeping }\end{array}$ & & & & & $\mathrm{X}$ \\
\hline ઠิ & $\begin{array}{c}17.12 . \\
2002\end{array}$ & $\begin{array}{c}01.01 . \\
2003\end{array}$ & $\begin{array}{c}31.12 . \\
2007\end{array}$ & $\begin{array}{l}\text { Decree No. } 23586 / 2002-92 \text { of } 17 \text { December } 2002 \text {, laying } \\
\text { down details of the accounting procedures and details of the } \\
\text { structure, description and content of items of financial } \\
\text { statements and the extent of data contained in these financial } \\
\text { statements to be published by entrepreneurs maintaining } \\
\text { accounts under the basis of cash receipts and disbursements, } \\
\text { doing business or undertaking other independent earning } \\
\text { activities where they report expenses incurred for acquiring, } \\
\text { assuring and maintaining income in order to determine their } \\
\text { income tax }\end{array}$ & & & $\mathrm{X}$ & & $\mathrm{X}$ \\
\hline 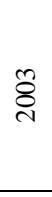 & $\begin{array}{c}31.03 . \\
2003\end{array}$ & $\begin{array}{c}10.04 \\
2003\end{array}$ & $\begin{array}{c}31.12 . \\
2014\end{array}$ & $\begin{array}{l}\text { Decree No. } 4455 / 2003-92 \text { of } 31 \text { March } 2003 \text {, laying down } \\
\text { details of the structure, description and content of items of } \\
\text { financial statements for an individual entity and the extent of } \\
\text { data contained in these financial statements to be published by } \\
\text { entrepreneurs maintaining accounts under the system of } \\
\text { double entry bookkeeping }\end{array}$ & & & $\mathrm{X}$ & & $\mathrm{X}$ \\
\hline$\tilde{\overbrace{}}$ & $\begin{array}{c}11.11 \\
2003\end{array}$ & $\begin{array}{c}01.12 . \\
2003\end{array}$ & $\begin{array}{l}31.12 . \\
2004\end{array}$ & $\begin{array}{l}\text { Decree No.16680/2003-92 of } 11 \text { November } 2003 \text { laying down } \\
\text { details of the methods and accounting procedures of } \\
\text { consolidation and consolidated financial statements }\end{array}$ & & & & $\mathrm{X}$ & $\mathrm{X}$ \\
\hline हे & $\begin{array}{c}13.12 . \\
2007\end{array}$ & $\begin{array}{c}01.01 . \\
2008\end{array}$ & & $\begin{array}{l}\text { Decree No. MF/27076/2007-74 of } 13 \text { December } 2007 \text {, laying } \\
\text { down details of the accounting procedures and details of the } \\
\text { structure, description and content of items of financial } \\
\text { statements and the extent of data contained in these financial } \\
\text { statements to be published by entrepreneurs maintaining } \\
\text { accounts under the basis of a cash receipts and disbursements, } \\
\text { doing business or undertaking other independent earning } \\
\text { activities where they report expenses incurred for acquiring, } \\
\text { assuring and maintaining income in order to determine their } \\
\text { income tax }\end{array}$ & & & $\mathrm{X}$ & & $\mathrm{X}$ \\
\hline
\end{tabular}


The International Journal

ENTREPRENEURSHIP AND SUSTAINABILITY ISSUES

ISSN 2345-0282 (online) http://jssidoi.org/jesi/ 2018 Volume 6 Number 1 (September) http://doi.org/10.9770/jesi.2018.6.1(11)

\begin{tabular}{|c|c|c|c|c|c|c|c|c|c|}
\hline \multirow[b]{3}{*}{$\stackrel{\nexists}{\nexists}$} & \multicolumn{4}{|r|}{ Legislation } & \multicolumn{5}{|c|}{ Accounting regulation spheres } \\
\hline & \multirow[b]{2}{*}{$\begin{array}{l}\text { issue } \\
\text { date }\end{array}$} & \multirow[b]{2}{*}{$\begin{array}{l}\text { effect } \\
\text { date }\end{array}$} & \multirow[b]{2}{*}{$\begin{array}{l}\text { cancel } \\
\text { ation } \\
\text { date }\end{array}$} & \multirow[b]{2}{*}{ type and title } & \multirow[b]{2}{*}{ 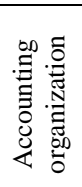 } & \multirow[b]{2}{*}{ 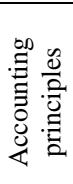 } & \multicolumn{2}{|c|}{ Reporting } & \multirow[b]{2}{*}{ 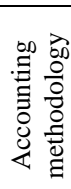 } \\
\hline & & & & & & & 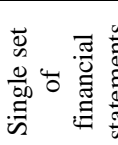 & 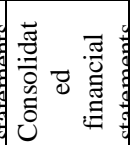 & \\
\hline$\stackrel{m}{\frac{\pi}{8}}$ & $\begin{array}{c}11.12 . \\
2013\end{array}$ & $\begin{array}{c}01.01 . \\
2014\end{array}$ & & $\begin{array}{l}\text { Decree No. MF/15464/2013-74 of } 11 \text { December } 2013 \text { laying } \\
\text { down details of the structure, description and content of items } \\
\text { of individual financial statements for micro accounting entities }\end{array}$ & & & $\mathrm{X}$ & & $\mathrm{X}$ \\
\hline$\stackrel{ \pm}{\text { ¿ }}$ & $\begin{array}{c}03.12 . \\
2014\end{array}$ & $\begin{array}{c}01.01 . \\
2015\end{array}$ & & $\begin{array}{l}\text { Decree No. MF/23377/2014-74 of } 3 \text { December } 2014 \text { laying } \\
\text { down details of the structure, description and content of items } \\
\text { of individual financial statements for large accounting entities } \\
\text { and public interest entities }\end{array}$ & & & $\mathrm{X}$ & & $\mathrm{X}$ \\
\hline 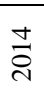 & $\begin{array}{c}03.12 . \\
2014\end{array}$ & $\begin{array}{c}01.01 . \\
2015\end{array}$ & & $\begin{array}{l}\text { Decree No. MF/23378/2014-74 of } 3 \text { December } 2014 \text { laying } \\
\text { down details of the structure, description and content of items } \\
\text { of individual financial statements for small accounting entities }\end{array}$ & & & $\mathrm{X}$ & & $\mathrm{X}$ \\
\hline
\end{tabular}

Source: Composed by authors according to references presented in the Table

In the meanwhile, the Ministry of Finance of the Slovak Republic accepted a proposal of two acts amending the Act on Accounting with effectiveness as of 1 January 2018. These two acts amend a delivery of documents to the tax authority or the electronic mailroom and the valuation of assets and liabilities by the European company, European cooperative or European economic interest group. One of the changes is connected with the more effective control of the observance of accounting legislation; the preservation of the accounting documentation will be prolonged from 5 years to 10 years. Besides it should be implemented the status of administrative offence having been committed repeatedly including the sanction for it. These proposals should assign some objectives of the Governmental Action Plan against Tax Fraud 2012-2016 (Mokošová, Subačienè, Hladika, Molín, 2017).

At the present time except for the accounting legislation for entrepreneurs there are valid accounting decrees connected with Act on Accounting for banks; budgetary organizations, subsidized organizations, municipalities, state funds and institutions that are financed from the state budget; non-entrepreneurs (i.e. non-profit organizations, political parties, civic associations and other similar bodies); health insurance companies; the Social Insurance Company; the Export-Import Bank of the Slovak Republic; security traders; mutual funds, pension funds and supplementary pension funds and Deposit Guarantee Fund, Guarantee Fund for Investment and electronic money institutions. Accounting regulation in the public sector consists from several decrees which amendments were partially influenced by IPSASs (Kordošová, 2008).

\section{Research findings}

Comparison of research results is presented in the Appendix 1 and generalized accounting evolution division on phases - in Figure 2. 


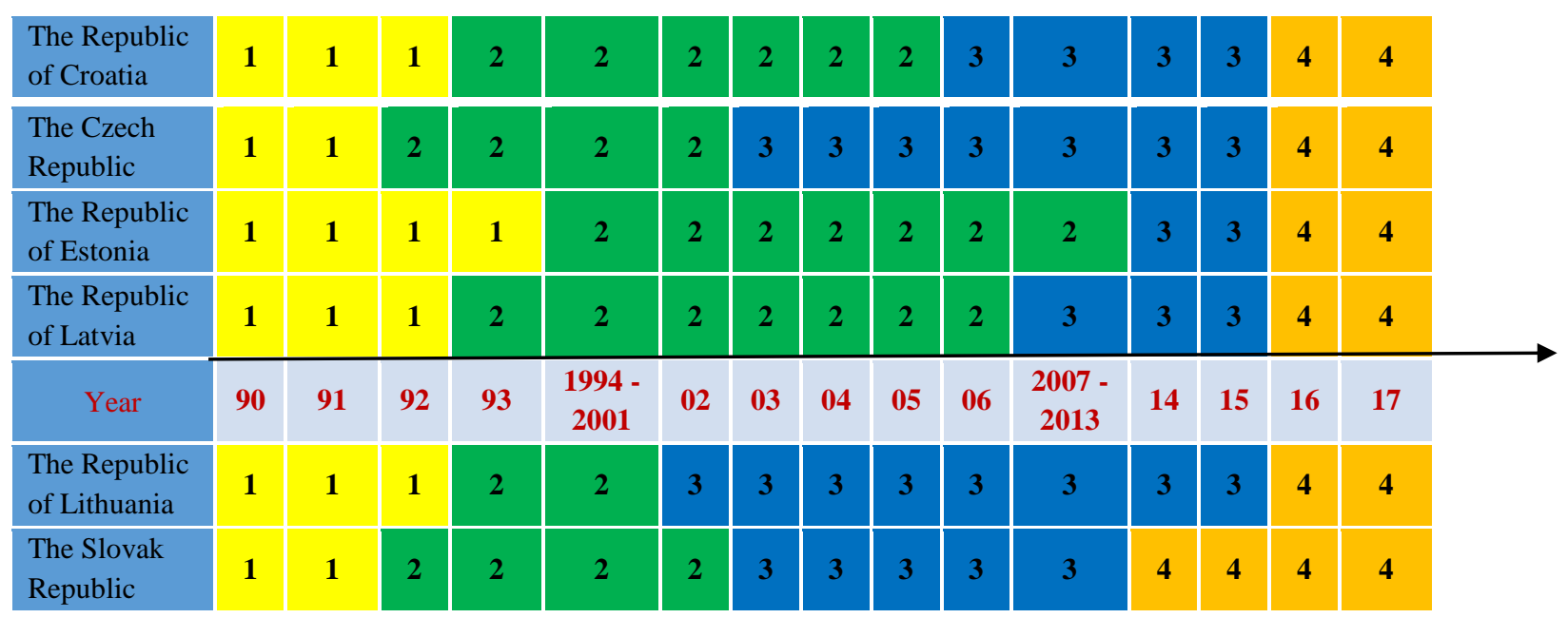

Fig. 2. Accounting regulation evolution division on phases

Source: Composed by authors

Research results show, that accounting regulation evolution phases are related with issue or amendments of Law (or Act) on Accounting and evolution of accounting regulation in analysed countries may be distinguished in four general phases. The period of evolution started at the beginning of nineties (1990-1993) when the countries transformed from a central planned economy to market economy, accounting performed as a central planned economy. Accounting system was reformed and substituted by completely new accounting regulation. Common factors influencing the development of the first phase are gaining the independence, transition from a central planned economy to market economy, social and economic changes, and emergence of new entrepreneurial entities. Common factors, which made impact for development of second phase (1992 - 2007), when laws on accounting and additional legislation were issued and accounting regulating laws were aligned with Fourth and Seventh EU Directives, are such as need for approving a comprehensive regulation of accounting, creation of an accounting system accessing the EU, stronger impact of globalization, beginning of the development of national accounting standards. Third phase (2003-2015) was devoted for further improvement of financial statement structure, implementation of IFRS and national accounting standards and were influenced by such common factors as necessity of improvement of influence of an economic crisis, issue of the new laws regulating accounting, the new setting of the application of a national accounting standards. Fourth phase (2012-present) express a significant influence on accounting regulatory acts of requirements of Directive 2013/34/EU of the European Parliament and Council and was influenced by factors of implementation of requirements of Directive 2013/34/EU into national Laws regarding accounting and diversification of composition and content of financial reports for different categories of companies.

Differences of analysed countries may be distinguished by several aspects (see Figure 3). Accounting system is regulated by one law in Croatia (Law on Accounting), The Czech Republic, The Slovak Republic, The Republic of Estonia (Accounting Act), but it is supplemented by many ordinances and decrees regarding accounting procedures, content and structure of financial statements, and by several laws in Latvia (Law on Accounting, Law on the Annual Financial Statements and Consolidated Financial Statements), in Lithuania (Law on Accounting; Law on Financial Statements; Law on Consolidated Financial Statements). The basic legal acts define the scope of accounting units, accounting principles, accounting organization, requirements for a single set of financial statements and consolidated financial statements, requirements for auditing and principles of accounting methodology. Significant problems (incoherent and unsystematic regulation of an accounting, 
different areas regulation by various legislation, does not exist sustainable accounting policy) caused many amendments of legal acts in all countries.

\begin{tabular}{|c|c|c|c|c|c|c|c|c|}
\hline & LA/AA & FCA & IFRS & NAS & IAAS & PSR & PSIAS & PSNAS \\
\hline \multicolumn{9}{|l|}{1990} \\
\hline 1991 & CZ, EE, SK & & LT & & $\mathrm{EE}$ & & & \\
\hline 1992 & & $\mathrm{CZ}, \mathrm{SK}$ & & & & & & \\
\hline 1993 & HR, LV, LT & & HR, LV & & HR & & & \\
\hline 1994 & & LT & & & & & & \\
\hline 1995 & & & & & LT & & & \\
\hline$\ldots$ & & & & & & & & \\
\hline 2002 & & & & & & HR & & \\
\hline 2003 & & & EE & $\mathrm{EE}$ & & & & \\
\hline 2004 & & & $\mathrm{CZ}$ & $\mathrm{CZ}, \mathrm{LT}$ & & & & \\
\hline 2005 & & & SK & & & $\mathrm{LT}$ & & \\
\hline 2006 & & & & & & & & LT \\
\hline 2007 & & & & LV & & & & \\
\hline 2008 & & & & $\mathrm{HR}$ & & SK & & \\
\hline \multicolumn{9}{|l|}{2009} \\
\hline 2010 & & & & & & $\mathrm{CZ}$ & & \\
\hline$\ldots$ & & & & & & & & \\
\hline 2017 & & & & & & & & \\
\hline
\end{tabular}

Abbreviations:

LA/AA - Law on Accounting/ Act on Accounting; FCA - Framework of Chart of Accounts; IFRS - International Financial Reporting standards; NAS -

National Accounting Standards; IAAS - Organization for Accounting and/or Accounting Standards; PSR - Public Sector Reform; PSNAS - Public Sector National Accounting Standards; PSIAS - Public Sector International Accounting Standards.

Source: Composed by authors

Application of the IFRS is a common feature in the countries under study because they all are the member states of the EU, however in Croatia and Estonia there is a possibility to apply IFRS or local Financial Reporting Standards for micro, small and medium companies as well. It was concluded that national accounting standards were introduced in Croatia, Czech Republic, Lithuania and Latvia, however in Latvia the Cabinet of Ministers ruled out the mandatory use of standards in accounting records of undertakings from 2011.

Although Croatia entered the European Union only in 2013, its accounting system's development stages, regulatory measures and requirements are similar to other countries involved in the study, so the hypothesis that newly formed, independent European countries accounting development depends on accession to the European Union should be rejected.

Reform of public sector accounting was performed in The Republic of Croatia, The Republic of Lithuania, and the Slovak Republic, when the cash basis of accounting in public sector accounting transferred to accrual basis of accounting or modified accrual basis of accounting (the Republic of Croatia). In the Czech Republic before 2010 public sector entities kept accrual based accounting (not cash based accounting) but with limited methods. 
National public sector accounting and financial reporting standards were issued only in Lithuania. In the Slovak Republic public sector accounting regulation consists from several decrees which amendments were partially influenced by IPSASs.

\section{References}

Act No. 21/1971 Coll., on Uniform System of Social-Economic Information

Act No. 431/2002 Coll. on Accounting as amended

Act No. 563/1991 Coll. on Accounting

Alver, J., Alver, L. 2008. Development of Accounting and Implementation of international Financial Reporting Standards in Estonia, in McGee, R. W. (Ed.) Accounting Reform in Transition and Developing Economies. New York: Springer, 101-113.

Alver, J., Alver, L., Mackevicius, J., Paupa, V., Bailey, D. 2001. Baltic States. In Alexander, D; Acher, S (Eds) European Accounting Guide, New York: Harcourt Brace Professional Publishing, 1481-1504.

Bikiene, J. 2011. Viešojo sektoriaus apskaitos ir finansinès atskaitomybės standartų igyvendinimo praktikoje problematika [Problems of Public Sector Accounting and Financial Reporting Standards Implementation into Practice] Verslas: teorija ir praktika [Business: Theory and Practice], No. 2011 12(2): 131-140. DOI: 10.3846/btp.2011.14. Available on the Internet: http://etalpykla.lituanistikadb.lt/fedora/objects/LT-LDB-0001:J.04 2011 1367181609757/datastreams/DS.002.0.01.ARTIC/content.

Brūna I., Millere I. The impact of the new Accounting Directive (2013/34/EU) on the normative Regulations of the Republic of Latvia. International scientific conference "New challenges of economic and business development-2014", 8-10 May, 2014, Riga : Conference proceedings / organised by Faculty of Economics and Management, University of Latvia in cooperation with Latvian European Community Studies Association ... [u.c.]. Riga: University of Latvia, 2014 P.52-64: tab. , URL: https://dspace.lu.lv/dspace/handle/7/5410 ISBN 9789984458366.

Brūna I., Millere I., Šneidere R. Accounting Policy and Developmental Issue in Latvia. Rachunkowość W Zarządzaniu Jednostkami Gospodarczymi. Szczecin, 2006, 37. - 43.p.

Decree No. 281, 283/77 411/2000 of 10 November 2000 laying down details of the accounting procedures for accounting units under the basis of cash receipts and disbursements.

Decree No. 281/71 701/95 of 21 December 1995 laying down the content of financial statements for entrepreneurs.

Decree No. 281/89 759/2001 of 14 November 2001 laying down the framework for the chart of accounts and details of the accounting procedures for entrepreneurs.

Decree No. 281/97 417/2001 of 14 December 2001 laying down the content of financial statements for entrepreneurs.

Decree No. 312/2014 Coll. on conditions for compiling accounting statements for the Czech Republic (the consolidation degree of the state).

Decree No. 325/2015 Coll. implementing some provisions of Act No. 563/1991 Coll., on Accounting, as amended, for accounting units using the single-entry accounting.

Decree No. 410/2009 Coll. implementing some provisions of Act No. 563/1991 Coll., on Accounting, as amended, for selected accounting units (state administration).

Decree No. 500/2002 Coll. implementing some provisions of Act No. 563/1991 Coll., on Accounting, as amended, for accounting units that are entrepreneurs using the double-entry accounting system.

Decree No. 501/2002 Coll. implementing some provisions of Act No. 563/1991 Coll., on Accounting, as amended, for accounting units that are banks and other financial institutions. 
Decree No. 502/2002 Coll. implementing some provisions of Act No .563/1991 Coll., on Accounting, as amended, for accounting units that are insurance companies.

Decree No. 503/2002 Coll. implementing some provisions of Act No. 563/1991 Coll., on Accounting, as amended, for health insurance companies.

Decree No. 504/2002 Coll. implementing some provisions of Act No. 563/1991 Sb., on Accounting, as amended, for accounting units whose objects clause is not business, providing they use the double-entry accounting system.

Decree No. 506/2002 Coll. implementing some provisions of Act No. 563/1991 Coll., on Accounting, as amended, for the following accounting units: National Property Fund of the Czech Republic and National Land Fund of the Czech Republic.

Decree No. 507/2002 Coll. implementing some provisions of Act No. 563/1991 Coll., on Accounting, as amended, for accounting units using the single-entry system.

Decree No. V/1- 31 388/1992 of 29 December 1992 laying down the structure and content of items of the balance sheet and the income statement for entrepreneurs.

Decree No. V/1-31 370/1992 of 23 December 1992 laying down details of the accounting procedures for sole traders carrying out business activities or other activities generating income under the basis of cash receipts and disbursements.

Decree No. V/20 100/1992 of 15 July 1992 laying down the framework for the chart of accounts and details of the accounting procedures for entrepreneurs.

Decree of the Ministry of Finance of the Czech Republic No. 23/1990 Coll., on Accounting.

Decree of the Ministry of Finance of the Slovak Republic No. 23054/2002-92 of 16 December 2002 laying down details of the accounting procedures and the framework for the chart of accounts for entrepreneurs maintaining accounts under the system of double entry bookkeeping, as amended.

Decree of the Ministry of Finance of the Slovak Republic No. MF/15464/2013-74 of 11 December 2013 laying down details of the structure, description and content of items of individual financial statements for micro accounting entities, as amended.

Decree of the Ministry of Finance of the Slovak Republic No. MF/23377/2014-74 of 3 December 2014 laying down details of the structure, description and content of items of individual financial statements for large accounting entities and public interest entities, as amended.

Decree of the Ministry of Finance of the Slovak Republic No. MF/23378/2014-74 of 3 December 2014 laying down details of the structure, description and content of items of individual financial statements for small accounting entities, as amended.

Directive 2013/34/EU of the European Parliament and of the Council on the annual financial statements, consolidated financial statements and related reports of certain types of undertakings, amending Directive 2006/43/EC of the European Parliament and of the Council and repealing Council Directives 78/660/EEC and 83/349/EEC 26 June 2013, 2017. Available on the Internet: http://eur-lex.europa.eu/legalcontent/EN/TXT/?uri=celex:32013L0034.

Farkaš, R. 2013. Konsolidovaná účtovná závierka v Slovenskej republike [Consolidated Financial Statements in the Slovak Republic]. Bratislava: Iura Edition, p. 309.

Gulin, D., Spajić, F., Spremić, I., Tadijančević, S., Vašiček, V., Žager, K., Žager, L., Računovodstvo [Accounting], 2003. Zagreb: Hrvatska zajednica računovođa i financijskih djelatnika.

Hladika, M., Mokošová, D., Molín, J. 2017. Comparison of national accounting framework-the case of Croatia, Slovakia and Czechia. In Economy of Eastern Croatia-vision and growth. International scientific symposium. Economy of Eastern Croatia-vision and growth : 6th International scientific symposium: Osijek, 25-27 May 2017, Croatia. - Osijek: Sveučilište Josipa Jurja Strossmayera u Osijeku, Ekonomski fakultet u Osijeku.

Hladika, M., Perspektiva primjene modela obračunske osnove i Međunarodnih računovodstvenih standarda za javni sektor u proračunsko računovodstvo u Republici Hrvatskoj [The perspectives of the application of the accrual basis of accounting and the International public sector accounting standards to government accounting in Croatia], 2013, doktorski rad. Zagreb: Ekonomski fakultet. 


\section{The International Journal}

ENTREPRENEURSHIP AND SUSTAINABILITY ISSUES

ISSN 2345-0282 (online) http://jssidoi.org/jesi/

2018 Volume 6 Number 1 (September)

http://doi.org/10.9770/jesi.2018.6.1(11)

Huleš J., Jeřábek A, 2001. Act on Accounting valid from 1 January 2002. Bilance, Prague 2001.

Kordošová, A. 2008. Základné zmeny v účtovníctve rozpočtových organizácií v kontexte IPSAS [Basic Changes in Accounting of Budgetary Organisations in accordance with IPSAS]. In Teória a prax v účtovníctve a $v$ auditorstve-jej miesto v prostredí uplatñujúcom prvky vedomostnej ekonomiky: zborník príspevkov zo štvrtého vedeckého seminára $k$ výsledkom vedeckovýskumnej činnosti Katedry účtovníctva a auditorstva. - Bratislava: Vydavatel'stvo EKONÓM.

Kunitsyna, N.; Britchenko, I.; Kunitsyn, I. 2018. Reputational risks, value of losses and financial sustainability of commercial banks, Entrepreneurship and Sustainability Issues 5(4): 943-955. https://doi.org/10.9770/jesi.2018.5.4(17)

Lakis, V., Subačienė, R. 2014. Transformation of Accounting in Lithuania since 1990, Zeszyty teoretyczne rachunkowosci [Theoretical Journal of Accounting], tom 78 (134).Warsaw, SKwP, 177-196.

Lietuvos Respublikos Buhalterinès apskaitos įstatymas [the Law on Accounting] No. IX-574, 6 November, 2001. 2017. Available on the Internet: https://www.e-tar.lt/portal/lt/legalAct/TAR.43178AA9832E.

Lietuvos Respublikos Buhalterinès apskaitos pagrindų įstatymas [the Law on the Principles of Accounting] No.I-2654, 18 June, 1992. 2017. Available on the Internet: https://www.e-tar.lt/portal/lt/legalAct/TAR.F15B67B048EB.

Lietuvos Respublikos İmonių finansinès atskaitomybès ịstatymas [The Law on Financial Statements] No. IX-575, 6 November 2001. 2017. Available on the Internet: https://www.e-tar.lt/portal/lt/legalAct/TAR.132D0D75309C.

Lietuvos Respublikos İmonių grupių konsoliduotosios finansinès atskaitomybès įstatymas [The Law on Consolidated Financial Statements] No. IX-576, 6 November 2001. 2017. Available on the Internet: https://www.e-tar.lt/portal/lt/legalAct/TAR.AB44F084071E.

Lietuvos Respublikos Viešojo sektoriaus atskaitomybès ịstatymas [The Law on Public Sector Reporting] No. X-1212, 26 June 2007. 2017. Available on the Internet: https://www.e-tar.lt/portal/lt/legalAct/TAR.E2CE2C82DA9E.

Lietuvos Respublikos Vyriausybès nutarimas "Dèl buhalterinès apskaitos ir atskaitomybès organizavimo" [Resolution of Government of Republic of Lithuania Due to Organization of Accounting and Reporting], No. 564, 17 December, 1991. 2017. Available on the Internet: https://www.e-tar.lt/portal/lt/legalAct/TAR.D4B6A5A06CB4.

Lietuvos Respublikos Vyriausybės nutarimas "Dėl įmonių, turinčių juridinio asmens teises, metinės finansinės atskaitomybės" [Due to Annual Reporting of Legal Entities] No. 804, 27 October, 1993. 2017. Available on the Internet: https://www.etar.lt/portal/lt/legalAct/TAR.F85A0C48BCC7.

Lietuvos Respublikos Vyriausybės nutarimas "Dèl viešojo sektoriaus buhalterinès apskaitos ir finansinès atskaitomybès sistemos reformos koncepcijos ir koordinavimo ir priežiūros komisijos sudarymo" [On the Conceptual Framework of the Public Sector Accounting and Financial Reporting System Reform and the Formation of a Commission for the Coordination and Monitoring of the Reform] No. 718,29 June 2005. 2017. Available on the Internet: https://www.e-tar.lt/portal/lt/legalAct/TAR.9B7AEBC5504D.

Lietuvos Respublikos, Vyriausybès nutarimas "Dẻl pagrindinių fondų amortizacinių atskaitymų mokestinių normatyvų" [Resolution of Government of Republic of Lithuania Due the taxation rates of amortization deductions of fixed asstes], No. 368,14 December, 1990. 2017. Available on the Internet: https://www.e-tar.lt/portal/lt/legalAct/TAR.CA1280DE773F.

Mackevičius, J. 2005. Nepriklausomos Lietuvos buhalterinès apskaitos raida ir problemos (1990 - 2005 m.) [Development and Problems of Accounting of Independent Lithuania]. Apskaitos ir audito sistemų integracija ị Europos Sajungos erdvę. Nauji iššūkiai ir galimybės [Accounting and Audit System Integration into European Union Area. New Challenges and Opportunities]. Research papers. Vilnius: Lithuanian chamber of auditors.

Mackevičius, J., Subačienè, R. 2016. Lithuanian Accounting Development Phases and Tendencies, Zeszyty Teoretyczne Rachunkowości [Theoretical Journal of Accounting] tom 88 (144): 87-107. Available on the Internet: $\underline{\text { http://ztr.skwp.pl/abstracted.php?level=5\&ICID=1212005\# }}$

Mackevičius, J., Subačienė, R. 2016a. Lietuvos buhalterinès apskaitos Sistema: praeitis, dabartis, perspektyvos [Lithuanian accounting system: past, present and prospects]. Vilnius: Akademinè leidyba. 
Mackevičius, J., Zverovich, S., Kazlauskienè, L. 2011. Financial Reporting in Lithuania, Harmonization of SME's Financial Reporting in Emerging CEE Countries, 1 part. WSEAS Press, 138-168.

Mejzlík L., Vítek L., Roe J., 2014. Adjustments to Accounting Profit in Determination of the Income Tax Base: Evolution in the Czech Republic in European Financial and Accounting Journal, No. 4, Year 2014. University of Economics, Prague. Available on the Internet: https://www.vse.cz/polek/download.php?lang=en\&jnl=efaj\&pdf=127.pdf.

MFRE 2015. Changes in Estonian legal framework and practices of accounting and auditing during 2004-2014. Available on the Internet: http://www.fin.ee/arvestuslal-arengud.

Millere I. Implementing the legislative requirements in Latvian accounting. Vilnius, Accounting \& Audit System Integration into European Union Area, new challenges and opportunities. The Papers of International Conference (6-7th October 2005), 2005. - 152.-158.p.

Millere I. Latvijas grāmatvedības vēsturiskās attīstības tendences. Rīga: Latvijas Universitāte, Latvijas Universitātes raksti, 689.sējums, 2005. - 201.-212.pp.

Mokošová, D., Subačienė, R, Hladika, M., Molín, J. 2017. Impact of changes in accounting regulation on sanctions for its violation in selected countries. In Financial Management of Firms and Financial Institutions 2017. $11^{\text {th }}$ International Scientific conference: Ostrava. (print version in proceeding).

Pacter, P. 2016. Estonia, IFRS as global standards: A pocket guide. London: IFRS Foundation.

Parišová, R. 2010. Podnikové kombinácie podl’a IFRS [Business Combination in accordance with IFRS]. Bratislava: Iura Edition, p. 173.

Paseková, M.; Müllerová, L.; Crhová, Z.; Svitaková, B. 2018. Impact of reporting of deferred tax on sustainable development of a counry: case of Czech Republic, Journal of Security and Sustainability Issues 7(4): 769-779. https://doi.org/10.9770/jssi.2018.7.4(13)

Pravilnik o financijskom izvještavanju u proračunskom računovodstvu, 2015, Official Gazette, No. 3/15, 93/15, 135/15, 2/17, 28/17. [Ordinance for financial reporting in public sector accounting].

Pravilnik o proračunskom računovodstvu i računskom planu, 2014, Official Gazette, No. 124/14, 57/15, 115/15, 87/16. [Ordinance for public sector accounting and chart of accounts].

Pravilnik o strukturi i sadržaju godišnjih financijskih izvještaja, 2008, Official Gazette, No. 38/08, 12/09, 130/10. [Ordinance on the structure and content of annual financial statements].

Pravilnik o strukturi i sadržaju godišnjih financijskih izvještaja, 2016, Official Gazette, No. 95/16. [Ordinance on the structure and content of annual financial statements].

Procházka, D. 2014. The IFRS as Tax Base: Potential Impact on a Small Open Economy in European Financial and Accounting Journal, No. 4, Year 2014. University of Economics, Prague. Available on the Internet: https://www.vse.cz/polek/download.php?lang=en\&jnl=efaj\&pdf=130.pdf

Raamatupidamise põhimäärus 1990, Riigiteataja [The Regulation on Accounting 1990] https://www.riigiteataja.ee/akt/24041.

Raamatupidamise seadus 1995, Riigiteataja [The Accounting Act] https://www.riigiteataja.ee/akt/28680.

Raamatupidamise seadus 2003-2015, Riigiteataja [The Accounting Act] https://www.riigiteataja.ee/akt/125052012016.

Raamatupidamise seadus 2015-2016, Riigiteataja [The Accounting Act] https://www.riigiteataja.ee/akt/127122016003.

Raamatupidamise seadus 2017, Riigiteataja [The Accounting Act] https://www.riigiteataja.ee/akt/127122016003?leiaKehtiv.

Regulation of the Cabinet of Ministers of Latvia No 201 Regulations on Obligatory Applicable Latvian Accounting Standards.18.10.2015. 
Regulations of the Cabinet of Ministers of Latvia No 775 Application Rules of the Law on the Annual Financial Statements and Consolidated Financial Statements.22.12.2015. https://likumi.lv/ta/id/278844-gada-parskatu-un-konsolideto-gada-parskatu-likumapiemerosanas-noteikumi.

Skálová, J. 2017. Taxes in Accounting. Wolters Kluwer, Prague 2001.

Šlosár, R. 2008. Dejiny účtovníctva na Slovensku [History of Accounting in Slovakia]. Bratislava: Iura Edition, p. 234.

Strichko, E. G. 2013. Costs of Accounting Information Support, Contemporary Economic Issues 4. https://doi.org/10.24194/41313

Subačienė, R., Mačerinskienè, A., Budrionytė, R. 2012. Apskaitos standartu harmonizavimas [Harmonization of Accouting Standards] "Accounting, audit, analysis: science in the context of innovation and globalization" research papers of international scientific conference 2012, Vilnius: Vilniaus universiteto leidykla, $713-722$.

The Law of the Republic of Latvia On Accounting.14.10.1992.

http://www.fm.gov.lv/files/gramatvedibaunrevizija/Law\%20on\%20Accounting\%20.pdf.

The Law of the Republic of Latvia On Budget and Financial Management.24.03.1994. https://likumi.lv/doc.php?id=58057.

The Law of the Republic of Latvia On the Annual Financial Statements and Consolidated Financial Statements. 22.10.2015. https:/likumi.lv/ta/id/277779-gada-parskatu-un-konsolideto-gada-parskatu-likums.

Zakon o proračunu, 1994, Official Gazette, No. 92/94. [Budget Law].

Zakon o proračunu, 2003, Official Gazette, No. 96/03. [Budget Law].

Zakon o proračunu, 2008, Official Gazette, No. 87/08, 136/12, 15/15. [Budget Law].

Zakon o računovodstvu, 1991, Official Gazette, No. 53/91, 33/92. [Law on Accounting].

Zakon o računovodstvu, 1992, Official Gazette, No. 90/92. [Law on Accounting].

Zakon o računovodstvu, 2005, Official Gazette, No. 146/05. [Law on Accounting].

Zakon o računovodstvu, 2007, Official Gazette, No. 109/07, 54/13. [Law on Accounting].

Zakon o računovodstvu, 2015, Official Gazette, No. 78/15, 134/15, 120/16. [Law on Accounting].

Zakon o registru godišnjih financijskih izvještaja, 2003, Official Gazette, No. 47/03. [Law on registry of annual financial statements] Zakon o trgovačkim društvima, 1993, Official Gazette, No. 111/93, 34/99, 121/99, 52/00, 118/03, 107/07, 146/08, 137/09, 125/11, 152/11, 111/12, 68/13, 110/15. [Company Law].

Žárová, M. 2013. Could New Accounting Directive Improve European Financial Reporting? - Introduction to European Financial and Accounting Journal, No. 2, Year 2013. University of Economics, Prague. Available on the Internet: https://www.vse.cz/polek/download.php?jnl=efaj\&pdf=97.pdf

Бухгалтерский учет в зарубежных странах_Accountancy in foreign countries]. 2007. под. редакцией Ф.Ф. Бутынца. Житомир, ЖГТУ. 
The International Journal

ENTREPRENEURSHIP AND SUSTAINABILITY ISSUES

ISSN 2345-0282 (online) http://jssidoi.org/jesi/

2018 Volume 6 Number 1 (September)

http://doi.org/10.9770/jesi.2018.6.1(11)

Short biographical note about the contributors at the end of the article (name, surname, academic title and scientific degree, duties, research interests):

Dr. Rasa SUBAČIENÉ is the Professor at the Department of Accounting and Audit, Faculty of Economics and Business Administration, Vilnius University, Lithuania. She is a member of editorial board of journals: "ETAP: Economic Theory, Analysis, Practice"; "Latgale National Economy Research"; "Science and Studies of Accounting and Finance: Problems and Perspectives". Research interests: financial accounting, management accounting, analysis of activity of enterprises.

ORCID ID: orcid.org/0000-0001-6559-8478

Lehte ALVER is the Professor at the Department of Business Administration, Faculty of Business and Governance, Tallinn University of Technology, Estonia. She is a member of editorial board of journals: Journal Zeszyty Teoretyczne Rachunkowosci (Theoretical Journal of Accounting), Journal of Accounting and Management Information Systems, Journal of Accounting, Ethics \& Public Policy. She is board member and national coordinator of European Accounting Association. Reserach interests: financial accounting, international accounting, accounting history and education.

ORCID ID: orcid.org/0000-0002-0895-3231

Dr. Inta BRUNA is the Professor at the Department of Finance and Accounting, Faculty of Business, Management and Economics, University of Latvia, Latvia. She has been the member of the scientific boards of several international conferences such as: 14th Biennial Conference 2014 for the International Society for the Study of Work and Organizational Values, 2nd Dubrovnik International Economic Meeting (DIEM) 2015 and in partner Universities in Vilnius and Tallinn. Research interests: financial accounting, internal audit, environmental accounting.

ORCID ID: orcid.org/0000-0002-4784-4476

Dr. Mirjana HLADIKA is the Assistant Professor at the Department of Accounting, Faculty of Economics and Business, University of Zagreb, Croatia. Her research interests include financial reporting, financial instruments, the implementation of IFRS, integrated reporting and management accounting. She is a member of editorial board of journals "Računovodstvo i financije" and "Riznica".

ORCID ID: orcid.org/0000-0003-3170-9138

Daša MOKOŠOVÁ, PhD. is the Assistent Professor at the Department of Accounting and Auditing, Faculty of Economic Informatics, at the University of Economics in Bratislava. Research interests: financial accounting, IFRSs, cost and management accounting, corporate governance.

ORCID ID: orcid.org/0000-0003-1829-6957

Jan MOLÍN, PhD. is the Assistant Professor and Deputy Head of Department of Financial Accounting and Auditing, Faculty of Finance and Accounting, University of Economics, Prague. He is a Chairman of Ethical Committee of the Chamber of Certified Accountants and Vice-Charman of the Commitee for Accounting Profession of the Union of Accountants. He is also a Tax Advisor, Examining Commissioner of the Chamber of Tax Advisors of the Czech Republic and Member of the Division for Matters Concerning the Profession of a Tax Advisor at the Chamber of Tax Advisors of the Czech Republic. He is a member of editorial board of the Bulletin of the Chamber of Certified Accountants. Research interests: financial accounting, relation between accounting and taxes, professional liability of auditors, tax advisors and accountants.

ORCID ID: orcid.org/0000-0003-0754-1363 
Appendix 1. Evaluation of accounting regulation evolution

\begin{tabular}{|c|c|c|}
\hline $\begin{array}{l}\text { Phases of accounting } \\
\text { regulation evolution }\end{array}$ & Factors influencing development of phases & Peculiarities of phases \\
\hline \multicolumn{3}{|c|}{ The Republic of Croatia } \\
\hline 1991-1992 & $\begin{array}{l}\text { gaining the independence; } \\
\text { transition from social (state) ownership to a } \\
\text { private one; } \\
\text { social and economic changes }\end{array}$ & $\begin{array}{l}\text { all business entities are in state ownership and accounting } \\
\text { is performed as a central planned economy; } \\
\text { accounting system is based on detailed rules and } \\
\text { instructions; } \\
\text { singular system of financial reporting }\end{array}$ \\
\hline 1993-2005 & $\begin{array}{l}\text { the first Law on Accounting in independent } \\
\text { Croatia is issued; } \\
\text { establishment of the Croatian Board for } \\
\text { Accounting and Accounting Standards }\end{array}$ & $\begin{array}{l}\text { abandon of accounting system that is based on detailed } \\
\text { rules and instructions; } \\
\text { chart of accounts is not prescribed; } \\
\text { dual system of financial reporting; } \\
\text { application of International Accounting Standards for all } \\
\text { business entities regardless their size; } \\
\text { establishment of Registry of financial statements }\end{array}$ \\
\hline 2006-2015 & $\begin{array}{l}\text { changes in accounting regulations are in } \\
\text { accordance with Croatia's accession to the EU; } \\
\text { establishment of the Board for Financial } \\
\text { Reporting Standards }\end{array}$ & $\begin{array}{l}\text { accounting regulation is aligned with Fourth and Seventh } \\
\text { EU Directives; } \\
\text { development and application of Croatian Financial } \\
\text { Reporting Standards; } \\
\text { new structure and content of financial statements }\end{array}$ \\
\hline 2016-present & $\begin{array}{l}\text { Implementation of requirements of Directive } \\
\text { 2013/34/EU into Croatia Law on Accounting }\end{array}$ & $\begin{array}{l}\text { significant changes in the accounting regulation for micro } \\
\text { entities (simplification of legislation) }\end{array}$ \\
\hline \multicolumn{3}{|c|}{ The Czech Republic } \\
\hline 1990-1991 & $\begin{array}{l}\text { a shift from a central planned economy to market } \\
\text { economy; occurrence of new entrepreneurial } \\
\text { entities }\end{array}$ & $\begin{array}{l}\text { approval of the decrees on accounting implementing the } \\
\text { act of } 1971 \text { on uniform system of social-economic } \\
\text { information }\end{array}$ \\
\hline 1992-2002 & $\begin{array}{l}\text { approval of the New Commercial Code and need } \\
\text { for approving a comprehensive regulation of } \\
\text { accounting }\end{array}$ & $\begin{array}{l}\text { approval of the new Act on accounting and implementing } \\
\text { decrees of the Ministry of Finance of the Czech Republic }\end{array}$ \\
\hline 2003-2009 & $\begin{array}{l}\text { need for a comprehensive regulation of } \\
\text { accounting through a legal regulation and for } \\
\text { detailed definition of accounting methods for } \\
\text { different types of accounting units }\end{array}$ & $\begin{array}{l}\text { the original decrees were replaced with new decrees } \\
\text { approved as a legal regulation; Czech accounting } \\
\text { standards were issued, defining particular accounting } \\
\text { procedures; legal regulation of single-entry accounting } \\
\text { was cancelled and replaced with tax record keeping (for } \\
\text { natural persons) and intended introduction of double- } \\
\text { entry accounting (for legal entities); application of the } \\
\text { IFRS was first compulsory, later voluntary }\end{array}$ \\
\hline 2010-2015 & $\begin{array}{l}\text { effort to make the information reported by state } \\
\text { administration more efficient and effort to } \\
\text { compile consolidated financial statements for the } \\
\text { Czech Republic }\end{array}$ & $\begin{array}{l}\text { "reform in accounting of state administration" was } \\
\text { applied through a new decree for state administration and } \\
\text { accounting methods used by accounting entities were } \\
\text { applied and decree on consolidation rules for state } \\
\text { administration was approved }\end{array}$ \\
\hline 2016-present & $\begin{array}{l}\text { requirements of Directive } 2013 / 34 / \mathrm{EU} \text { of the } \\
\text { European Parliament and of the Council of } 26 \\
\text { June } 2013 \text { and need to introduce further } \\
\text { legislative changes }\end{array}$ & $\begin{array}{l}\text { approval of an extensive amendment to Czech accounting } \\
\text { regulations }\end{array}$ \\
\hline \multicolumn{3}{|c|}{ The Republic of Estonia } \\
\hline 1990-1994 & $\begin{array}{l}\text { Restoration of the independence. Movement from } \\
\text { planned economy to free market. }\end{array}$ & $\begin{array}{l}\text { Regulation of Accounting was adopted. It was an } \\
\text { introduction of a fundamentally different accounting } \\
\text { system in comparison with the planned economy. } \\
\text { Establishment of Estonian Accounting Board. }\end{array}$ \\
\hline 1995-2002 & Formation of accounting system & $\begin{array}{l}\text { First Accounting Act was came into force. Accounting } \\
\text { Act was supplemented by } 16 \text { guidelines which were } \\
\text { called as Estonian GAAP. True and Fair View override }\end{array}$ \\
\hline
\end{tabular}




\begin{tabular}{|c|c|c|}
\hline $\begin{array}{l}\text { Phases of accounting } \\
\text { regulation evolution }\end{array}$ & Factors influencing development of phases & Peculiarities of phases \\
\hline & & was declared. \\
\hline 2003-2012 & Changes in accounting system & $\begin{array}{l}\text { New Estonian Accounting Act. The essence of the law is } \\
\text { framed in compliance with IFRSs. Two accounting } \\
\text { frameworks: Estonian GAAP and IFRSs. Estonian GAAP } \\
\text { is based to the IFRSs }\end{array}$ \\
\hline 2013-2015 & $\begin{array}{l}\text { Changes in Estonian GAAP: switch from the Full } \\
\text { IFRS to the IFRS for SMEs }\end{array}$ & $\begin{array}{l}\text { Estonian GAAP (17 guidelines) is based to the IFRS for } \\
\text { SMEs }\end{array}$ \\
\hline 2016-present & $\begin{array}{l}\text { Requirements of Directive 2013/34/EU of the } \\
\text { European Parliament and of the Council of } 26 \\
\text { June } 2013 \text {. }\end{array}$ & $\begin{array}{l}\text { Changes in the Accounting Act: diversification of entities } \\
\text { and changes of requirements of the content of annual } \\
\text { reports depending on the size of companies. From } 2017 \\
\text { the Estonian GAAP was renamed to the Estonian } \\
\text { financial reporting standard. }\end{array}$ \\
\hline \multicolumn{3}{|c|}{ The Republic of Latvia } \\
\hline 1991-1992 & $\begin{array}{l}\text { restoration of the independence; movement from } \\
\text { planned economy to free market; } \\
\text { significant changes of economics and social life }\end{array}$ & $\begin{array}{l}\text { the introduction of a fundamentally different accounting } \\
\text { system in comparison with the planned economy; the } \\
\text { obligation of companies to submit financial statements } \\
\text { and disclosure the information }\end{array}$ \\
\hline 1993-2006 & $\begin{array}{l}\text { creation of an accounting system; } \\
\text { accessing the EU; stronger impact of } \\
\text { globalization; beginning of the development of } \\
\text { national accounting standards }\end{array}$ & $\begin{array}{l}\text { accounting regulating laws alignment with Fourth and } \\
\text { Seventh EU Directives; unified fundamental principle of } \\
\text { bookkeeping in public sector; special regulations of } \\
\text { Cabinet of Ministers for the accounting organisation; } \\
\text { establishment of Methodological Council of an } \\
\text { Accounting }\end{array}$ \\
\hline 2007-2011 & $\begin{array}{l}\text { necessity of improvement of the rules regarding } \\
\text { the accounting regulations; influence of an } \\
\text { economic crisis }\end{array}$ & $\begin{array}{l}\text { development of national accounting standards instead } \\
\text { adaption the international accounting standards; changes } \\
\text { of the content of balance sheet; specified evaluation } \\
\text { methods; different audit criteria }\end{array}$ \\
\hline 2012-2015 & $\begin{array}{l}\text { stabilization policy of economics; } \\
\text { the new setting of the application of a national } \\
\text { accounting standards }\end{array}$ & $\begin{array}{l}\text { replacement of the national standards with the Cabinet of } \\
\text { Ministers regulations; improvement of the public sector } \\
\text { accounting in a post -crisis period }\end{array}$ \\
\hline 2016-present & $\begin{array}{l}\text { requirements of Directive 2013/34/EU of the } \\
\text { European Parliament and of the Council of } 26 \\
\text { June 2013; }\end{array}$ & $\begin{array}{l}\text { adoption of the law "On Annual Report and Consolidated } \\
\text { Annual Report"; diversification of composition and } \\
\text { content of financial reports for different categories of } \\
\text { companies }\end{array}$ \\
\hline \multicolumn{3}{|c|}{ The Republic of Lithuania } \\
\hline 1990-1992 & $\begin{array}{l}\text { the restoration of independence; } \\
\text { changeover from a state ownership to a private } \\
\text { one; social and economic changes }\end{array}$ & $\begin{array}{l}\text { accounting performed as a central planned economy } \\
\text { accounting system based on detailed rules and } \\
\text { instructions }\end{array}$ \\
\hline 1993-2001 & $\begin{array}{l}\text { issue of the Law on the Principles of Accounting; } \\
\text { establishment of the Institute of Audit and } \\
\text { Accounting }\end{array}$ & $\begin{array}{l}\text { accounting regulation started to develop from detail } \\
\text { instructions to appliance of principles; } \\
\text { regulation of accounting was not consistent, different } \\
\text { accounting' spheres were regulated by different level of } \\
\text { legislation; } \\
\text { enterprises proceeded accounting on tax laws } \\
\text { requirements }\end{array}$ \\
\hline 2002-2015 & $\begin{array}{l}\text { issue of the Law on Accounting, the Law on } \\
\text { Financial Statements, the Law on Consolidated } \\
\text { Financial Statements; changes related with the } \\
\text { Lithuania's accession to the EU; } \\
\text { issue of Business Accounting Standards }\end{array}$ & $\begin{array}{l}\text { the Law on Accounting, the Law on Financial } \\
\text { Statements, the Law on Consolidated Financial } \\
\text { Statements were complied with the Fourth (78/660/EEC) } \\
\text { and Seventh (83/349/EEC) EU directives; } \\
\text { Business Accounting Standards were based on } \\
\text { International Financial Reporting Standards }\end{array}$ \\
\hline 2016-present & $\begin{array}{l}\text { requirements of Directive } 2013 / 34 / \mathrm{EU} \text { of the } \\
\text { European Parliament and of the Council of } 26 \\
\text { June 2013; }\end{array}$ & $\begin{array}{l}\text { changes, related with this phase made the biggest impact } \\
\text { in arrangement of accounting for micro-enterprises }\end{array}$ \\
\hline
\end{tabular}


The International Journal

ENTREPRENEURSHIP AND SUSTAINABILITY ISSUES

ISSN 2345-0282 (online) http://jssidoi.org/jesi/ 2018 Volume 6 Number 1 (September)

http://doi.org/10.9770/jesi.2018.6.1(11)

\begin{tabular}{|c|c|c|}
\hline $\begin{array}{l}\text { Phases of accounting } \\
\text { regulation evolution }\end{array}$ & Factors influencing development of phases & Peculiarities of phases \\
\hline & $\begin{array}{l}\text { amended legislation related with regulation of } \\
\text { accounting }\end{array}$ & \\
\hline \multicolumn{3}{|c|}{ The Slovak Republic } \\
\hline $\begin{array}{c}1990-1992 \\
\text { (CSFR) }\end{array}$ & $\begin{array}{l}\text { changeover from a state ownership to a private } \\
\text { one; } \\
\text { social and economic changes }\end{array}$ & $\begin{array}{l}\text { accounting performed as a central planned economy } \\
\text { accounting system was reformed and substituted by } \\
\text { completely new accounting regulation }\end{array}$ \\
\hline 1993-2002 & the restoration of independence & $\begin{array}{l}\text { continuing with implemented CSFR's accounting } \\
\text { regulation with later amendments }\end{array}$ \\
\hline 2003-2013 & $\begin{array}{l}\text { new set of Slovak accounting regulation issued: } \\
\text { Act on Accounting, Decrees on accounting } \\
\text { procedures and decrees on financial statements } \\
\text { was published because of entrance negotiations of } \\
\text { the SR to the EU }\end{array}$ & $\begin{array}{l}\text { implementation of Fourth EU directive (78/660/EEC), the } \\
\text { Seventh EU directive (83/349/EEC), the Eight EU } \\
\text { directive (84/253/EEC), other EU directives which set } \\
\text { additional requirements in specific issues (e.g. individual } \\
\text { and consolidated financial statements of banks or } \\
\text { insurance companies) and partially IAS/IFRS }\end{array}$ \\
\hline 2014-present & $\begin{array}{l}\text { requirements of Directive 2013/34/EU of the } \\
\text { European Parliament and of the Council of } 26 \\
\text { June } 2013 \text { implemented }\end{array}$ & $\begin{array}{l}\text { changes, related with this phase made an impact in } \\
\text { arrangement of accounting and financial statements for } \\
\text { micro and small enterprises, Act on Accounting was } \\
\text { amended and new degrees on individual financial } \\
\text { statements were published }\end{array}$ \\
\hline
\end{tabular}

Source: Composed by authors 